Chemang Temneriog

Quviejer

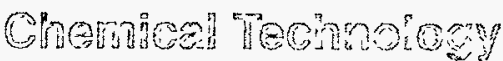

mingersis

Chemigal Tempongy Plingion?

Chemical Technology Division

Chemical Technology Division

Chemical Technology

\title{
Minimum Additive Waste Stabilization (MAWS), Phase I: - Soil Washing Final Report
} Division

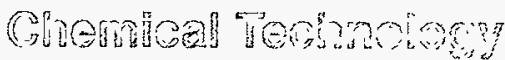
hisgiry

Cheming Tecmons

Disosios

Contract No. 21402401

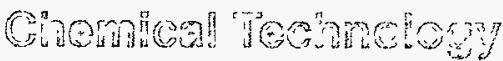

Piv" 390

Chomignt Honnofory

Din:

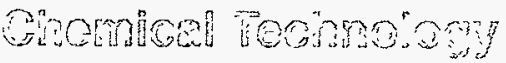

Dथल]

Bhement Technofos

Detoles?

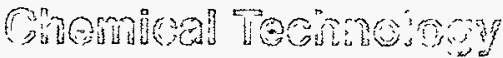

Qivg 320

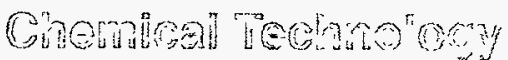

Butson

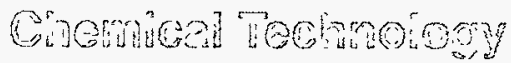

Divgon

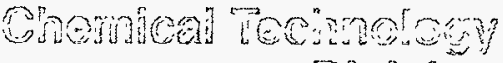

Bivero:

\author{
RECEIVED \\ JUL 221996 \\ OSTI
}

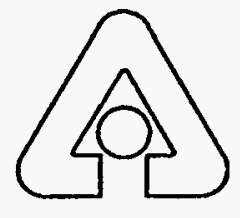

Argonne National Laboratory, Argonne, Illinois 60439

operated by The University of Chicago

for the United States Department of Energy under Contract W-31-109-Eng-38

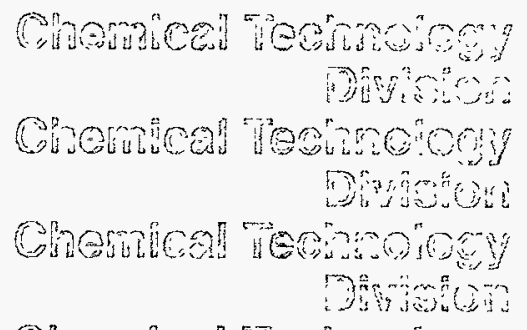

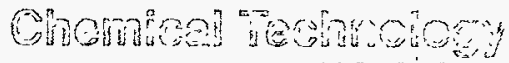


Argonne National Laboratory, with facilities in the states of Illinois and Idaho, is owned by the United States government, and operated by The University of Chicago under the provisions of a contract with the Department of Energy.

\section{DISCLAIMER}

This report was prepared as an account of work sponsored by an agency of the United States Government. Neither the United States Government nor any agency thereof, nor any of their employees, makes any warranty, express or implied, or assumes any legal liability or responsibility for the accuracy, completeness, or usefulness of any information, apparatus, product, or process disclosed, or represents that its use would not infringe privately owned rights. Reference herein to any specific commercial product, process, or service by trade name, trademark, manufacturer, or otherwise, does not necessarily constitute or imply its endorsement, recommendation, or favoring by the United States Government or any agency thereof. The views and opinions of authors expressed herein do not necessarily state or reflect those of the United States Government or any agency thereof.

Reproduced from the best available copy.

Available to DOE and DOE contractors from the

Office of Scientific and Technical Information

P.O. Box 62

Oak Ridge, TN 37831

Prices available from (423) 576-8401

Available to the public from the

National Technical Information Service

U.S. Department of Commerce

5285 Port Royal Road

Springfield, VA 22161 


\section{DISCLAIMER}

Portions of this document may be illegible in electronic image products. Images are produced from the best available original document. 

Distribution Category:

General, Miscellaneous, and Progress Reports

(UC-600)

ANL-95/46

Argonne National Laboratory

9700 South Cass Avenue

Argonne, IL 60439

\section{MINIMUM ADDITIVE WASTE STABILIZATION (MAWS), PHASE I: SOIL WASHING FINAL REPORT}

Contract No. 21402401

by

Lockheed Environmental Systems and Technologies Company

under contract with

GTS Duratek, Inc.

8900 South Guilford Road, Suite 600

Columbia, MD 21046

Telephone: (410) 312-5100

Facsimile: (301) 621-8211

August 1995

Prepared for

Office of Research and Development

Technology Development, Environmental Restoration and Waste Management

U.S. Department of Energy

1000 Independence Avenue

Washington, DC 20585-0002

Research and Development Program Coordination Office

Waste Management and Technology Development, Chicago Field Office

U.S. Department of Energy

9800 South Cass Avenue

Argonne, IL 60439

Office of Waste Management Programs

Chemical Technology Division, Argonne National Laboratory

9700 South Cass Avenue, Argonne, IL 60439

under Prime Contract W-31-109-Eng-38 to the U.S. Department of Energy 


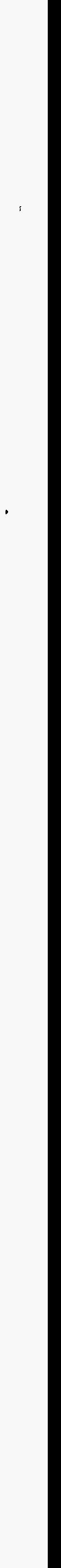




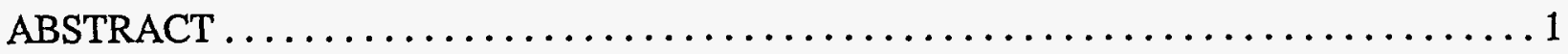

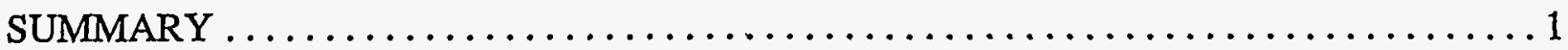

Project Objectives and Results ..............................

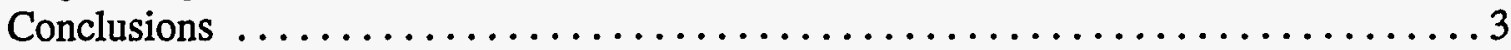

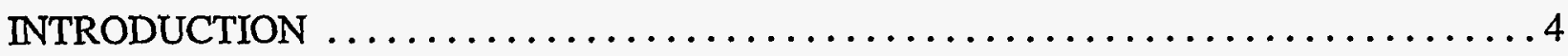

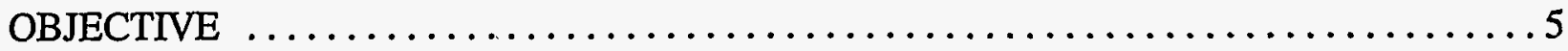

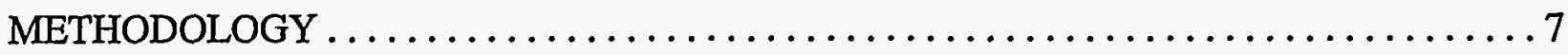

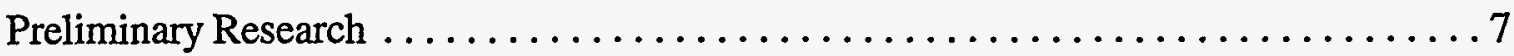

Design Considerations and Flow Diagram $\ldots \ldots \ldots \ldots \ldots \ldots \ldots \ldots \ldots \ldots \ldots$

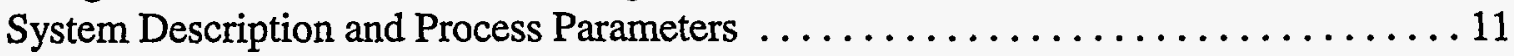

Physical Separation System $\ldots \ldots \ldots \ldots \ldots \ldots \ldots \ldots \ldots \ldots \ldots \ldots \ldots \ldots \ldots \ldots \ldots$

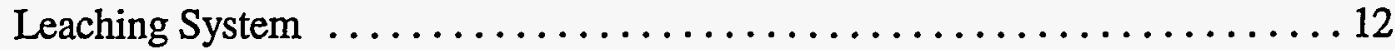

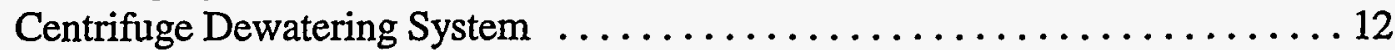

Instrumentation ..................................... 13

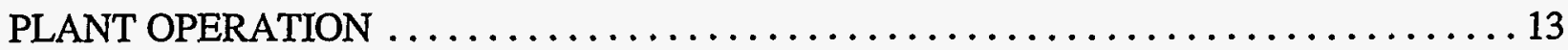

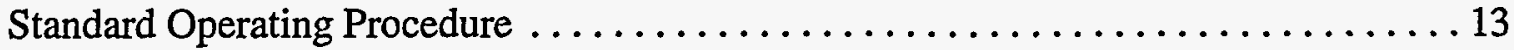

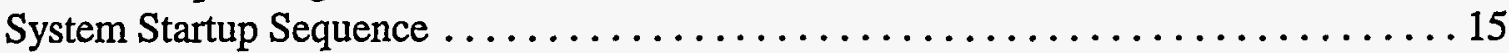

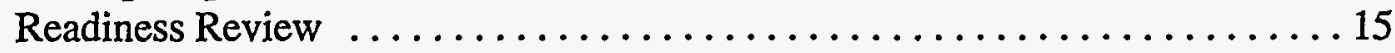

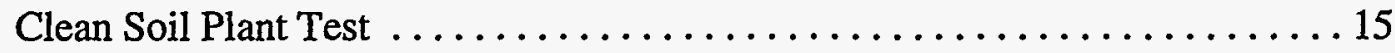

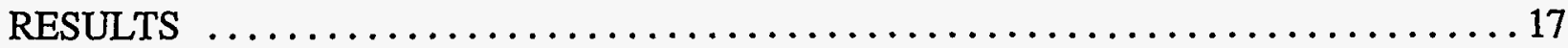

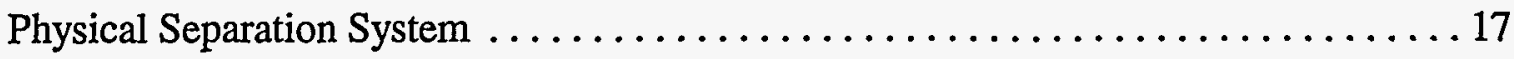

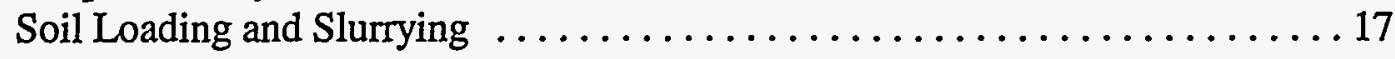

Screening and Cycloning $\ldots \ldots \ldots \ldots \ldots \ldots \ldots \ldots \ldots \ldots \ldots \ldots \ldots \ldots \ldots \ldots \ldots \ldots$

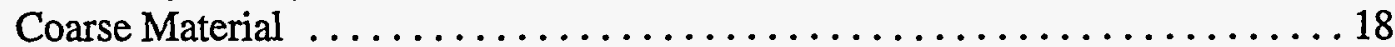

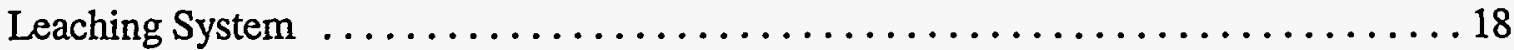

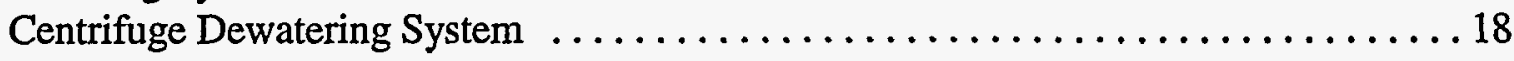

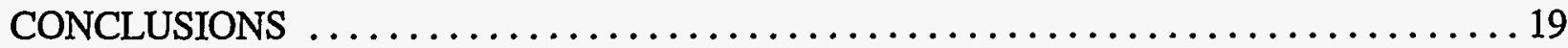

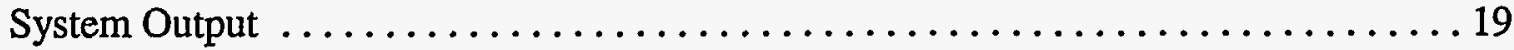

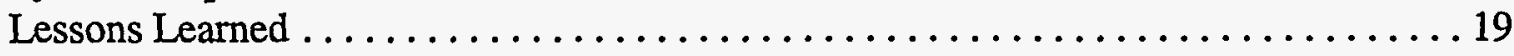

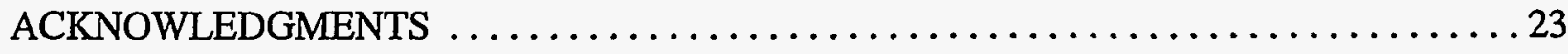

APPENDIX A. MASS BALANCE AND PIPING AND

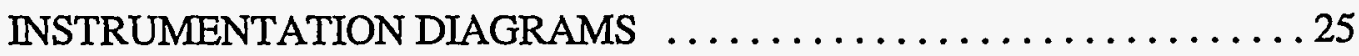

APPENDIX B. CONVERSION FACTOR BETWEEN ACTIVITY AND CONCENTRATION FOR FERNALD CONTAMINATED SOIL 


\section{LIST OF FIGURES}

No.

Title

Page

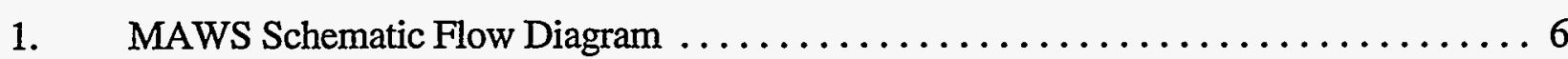

2. Schematic Flow Diagram of Proposed Soil Washing System $\ldots \ldots \ldots \ldots \ldots \ldots$

\section{LIST OF TABLES}

No.

Title

Page

1. Soil Size Distribution and Activity of Fernald Plant $1 \mathrm{Pad}$ Soils $\ldots \ldots \ldots \ldots \ldots .7$

2. Soil Size Distribution after Delumping $\ldots \ldots \ldots \ldots \ldots \ldots \ldots \ldots \ldots \ldots \ldots$

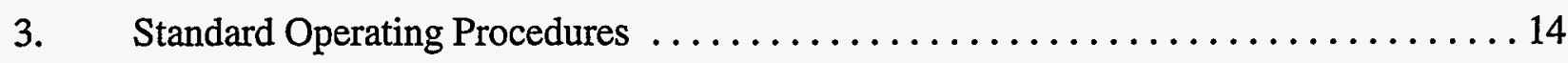

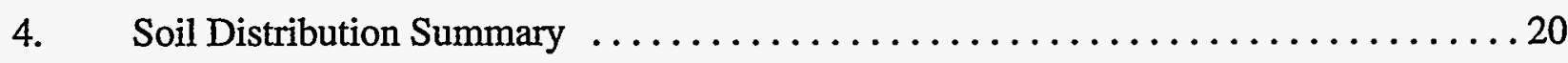

5. Chemical Consumption per Ton of Clean Soil Collected, for

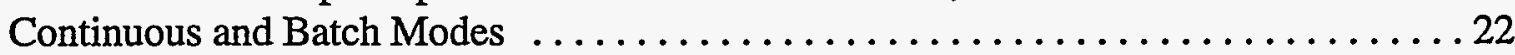

B.1. Specific Activities and Their Contribution to Total Radioactivity ..............41 


\title{
MINIMUM ADDITIVE WASTE STABILIZATION (MAWS), PHASE I: SOIL WASHING FINAL REPORT
}

by

\section{Lockheed Environmental Systems and Technologies Company}

\begin{abstract}
As a result of the U.S. Department of Energy's environmental restoration and technology development activities, GTS Duratek, Inc., and its subcontractors have demonstrated an integrated thermal waste treatment system at Fernald, $\mathrm{OH}$, as part the Minimum Additive Waste Stabilization (MAWS) Program. Specifically, MAWS integrates soil washing, vitrification of mixed waste streams, and ion exchange to recycle and remediate process water to achieve, through a synergistic effect, a reduction in waste volume, increased waste loading, and production of a durable, leach-resistant, stable waste form suitable for disposal. This report summarizes the results of the demonstration/testing of the soil washing component of the MAWS system installed at Fernald (Plant 9). The soil washing system was designed to (1) process contaminated soil at a rate of 0.25 cubic yards per hour; (2) reduce overall waste volume and provide consistent-quality silica sand and contaminant concentrates as raw material for vitrification; and (3) release clean soil with uranium levels below $35 \mathrm{pCi} / \mathrm{g}$. Volume reductions expected ranged from 50-80 percent; the actual volume reduction achieved during the demonstration reached 66.5 percent. The activity level of clean soil was reduced to as low as $6 \mathrm{pCi} / \mathrm{g}$ from an initial average soil activity level of $17.6 \mathrm{pCi} / \mathrm{g}$ (the highest initial level of soil provided for testing was $41 \mathrm{pCi} / \mathrm{g}$ ). Although the throughput of the soil washing system was inconsistent throughout the testing period, the system was online for sufficient periods to conclude that a rate equivalent to 0.25 cubic yards per hour was achieved.
\end{abstract}

\section{SUMMARY}

This report summarizes the findings of the Phase IDemonstration Testing of the soil washing system developed as part of the Minimum Additive Waste Stabilization (MAWS) Program. The system was designed and constructed by the Technical Application Division (TAD) of Lockheed Environmental Systems and Technologies Company (LESAT). The MAWS Program is an effort to demonstrate 
the cost-effectiveness and feasibility of waste volume reduction by an integrated system that combines

- soil washing with chemical leaching,

- ion exchange for water treatment and extraction of contaminants, and

- vitrification to stabilize the waste form.

This system demonstrated that a blended waste stream of Fernald Environmental Management Project (FEMP) soils and sludge from Pit 5 waste could be treated on a large scale to achieve

- overall waste volume reduction with minimum additives,

- waste water treatment to provide recycle water for the processes, and

- a stabilized waste form for disposal.

The soil washing system also was to provide (1) silica sand of consistent quality as raw material for vitrification to produce the stabilized waste form and (2) clean soil with uranium activity level below $35 \mathrm{pCi} / \mathrm{g}$ at a rate of 0.25 cubic yards per hour.

The waste water treatment and vitrification systems were designed and operated by GTS Duratek and Catholic University of America. This final report discusses the development, construction, and operation of the soil washing system for the demonstration.

The demonstration took place at Plant 9 of the former Feed Material Production Center at Fernald, Ohio, between December 14, 1993, and April 16, 1994. Argonne National Laboratory is the MAWS Contract Administrator, and the Fernald Environmental Restoration Management Company (FERMCO), on behalf of the U.S. Department of Energy (DOE), manages the FEMP and provides site support and environmental monitoring and radiation safety support.

\section{Project Objectives and Results}

The project objectives were to demonstrate the ability of the soil washing system to achieve

- contaminated soil volume reduction of 50 to 80 percent,

- reduction of the uranium activity of the treated soil to below $35 \mathrm{pCi} / \mathrm{g}$, and

- a process rate of 0.25 cubic yards per hour. 
The results of the demonstration in each of these areas were as follows:

- The average volume reduction of the demonstration was 66.5 percent.

- The average uranium activity of the treated soil of the demonstration was $6 \mathrm{pCi} / \mathrm{g}$.

- The throughput of the system was not as consistent as expected. However, there were periods during the demonstration when both the soil washing system and the waste water treatment system were online for a sufficient time to determine that the throughputs were higher than three drums of contaminated soils every 2.5 hours, a rate equivalent to 0.25 cubic yards per hour.

\section{Conclusions}

1. A combination of physical separation and chemical treatment are required to provide significant waste volume reduction.

2. The consistent-quality silica sands produced by the soil washing system provide the essential raw material for vitrification for waste stabilization.

3. Completion of the Phase I demonstration advances the integrated treatment concept, which is that an integrated system can more effectively reduce waste volume than the individual operations can when functioning independently.

4. Improvement of the overall efficiency of the integrated system requires optimization of the amount and the fractions of silica sands produced by the soil washing system. Any silica sand in excess of that required by vitrification will adversely affect the potential to meet volume reduction goals.

5. To maintain any sustained period of integrated operation, the filtration equipment should have sufficient capacity to handle design throughput plus 20 percent surge capacity. All major equipment must have realistic standby capacity to reduce downtime.

A discussion of lessons learned addresses problem areas and recommended modifications. 


\section{INTRODUCTION}

The Fernald Environmental Management Project (FEMP), formerly known as the Feed Materials Production Center, is located on 1050 acres, 20 miles northwest of downtown Cincinnati, OH. The FEMP is operated by the Fernald Environmental Restoration Management Company (FERMCO) on behalf of the U.S. Department of Energy (DOE). Between 1953 and 1989, the center produced slightly enriched or depleted uranium products used in production reactors at other DOE sites to make plutonium and tritium. However, uranium processing was suspended in 1989, and resources were focused on waste management and environmental restoration.

The Minimum Additive Waste Stabilization (MAWS) Program is an integrated waste treatment program designed to demonstrate the cost effectiveness and feasibility of waste volume reduction. The program combines three separate systems: soil washing and leaching, vitrification, and waste water treatment. This integrated system produces results that achieve a unique synergistic effect, an effect that is far greater than the sum of the results of the contributing systems functioning independently.

Argonne National Laboratory is the MAWS Contract Administrator. GTS Duratek is the prime contractor in charge of water treatment. GTS Duratek is working with two subcontractors: the Vitreous State Laboratory of the Catholic University of America (in charge of vitrification) and Lockheed Environmental Systems and Technologies Company (LESAT) (in charge of soil washing and leaching). The FEMP prepared the facility to house the MAWS equipment and provided environmental monitoring and radiation safety officer support.

The FEMP has more than 350,000 cubic meters of pit wastes and more than $2,000,000$ cubic meters of potentially contaminated soils on site that need to be remediated. Vitrification is an attractive remediation alternative for some site soils because in this process organic contaminants are completely oxidized to carbon dioxide and water, while radionuclides, heavy metals, and other inorganic contaminants are dissolved into the glass matrix, which has a very low leach rate.

Good glass is defined as glass that passes the glass performance tests that demonstrate the stability of the waste form. These tests include the U.S. Environmental Protection Agency Toxicity Characteristic Leaching Procedure test and the Savannah River Product Consistency Test (PCT), which is the present standard for high-level waste glasses. However, the sludges in the FEMP waste pits do not make good glass, because they do not contain sufficient silica-bearing compounds. The FEMP soils do make good glass, but their melting point is too high for economical operation. Based on preliminary results from laboratory studies, Pit 5 waste sludges behave as a flux that lowers the soil melting point, and together the pit waste sludge and soils do make good glass. 
Specifically, MAWS integrates soil washing (to separate contaminants from soils), vitrification of mixed waste streams, and ion exchange to remediate and recycle water from the soil washing process and the vitrification off-gas scrubber. Spent ion-exchange media are either regenerated or combined with other waste streams and vitrified.

The Phase I Demonstration Testing was a part of the MAWS plant test program to demonstrate the cost-effectiveness and feasibility of reducing waste volume by using the integrated system.

\section{OBJECTIVE}

The overall objective of the Phase I Demonstration Testing of MAWS was to determine the effectiveness of treating combined waste streams of FEMP contaminated soils and Pit 5 waste sludges to achieve the following:

- Overall waste volume reduction of 50 to 80 percent with a clean-soil uranium content below $35 \mathrm{pCi} / \mathrm{g}$ at a rate of 0.25 cubic yards per hour.

- Waste water treatment to provide recycle water for the processes (up to 50 gallons per minute).

- A stabilized waste form suitable for disposal.

The LESAT soil washing system was designed not only to meet the first objective, but also to provide consistent-quality silica sand as raw material for vitrification to produce stabilized waste.

Figure 1 is a schematic flow diagram that shows the integration of the various technologies into the MAWS system. 
Figure 1 - MAWS Schematic Flow Diagram

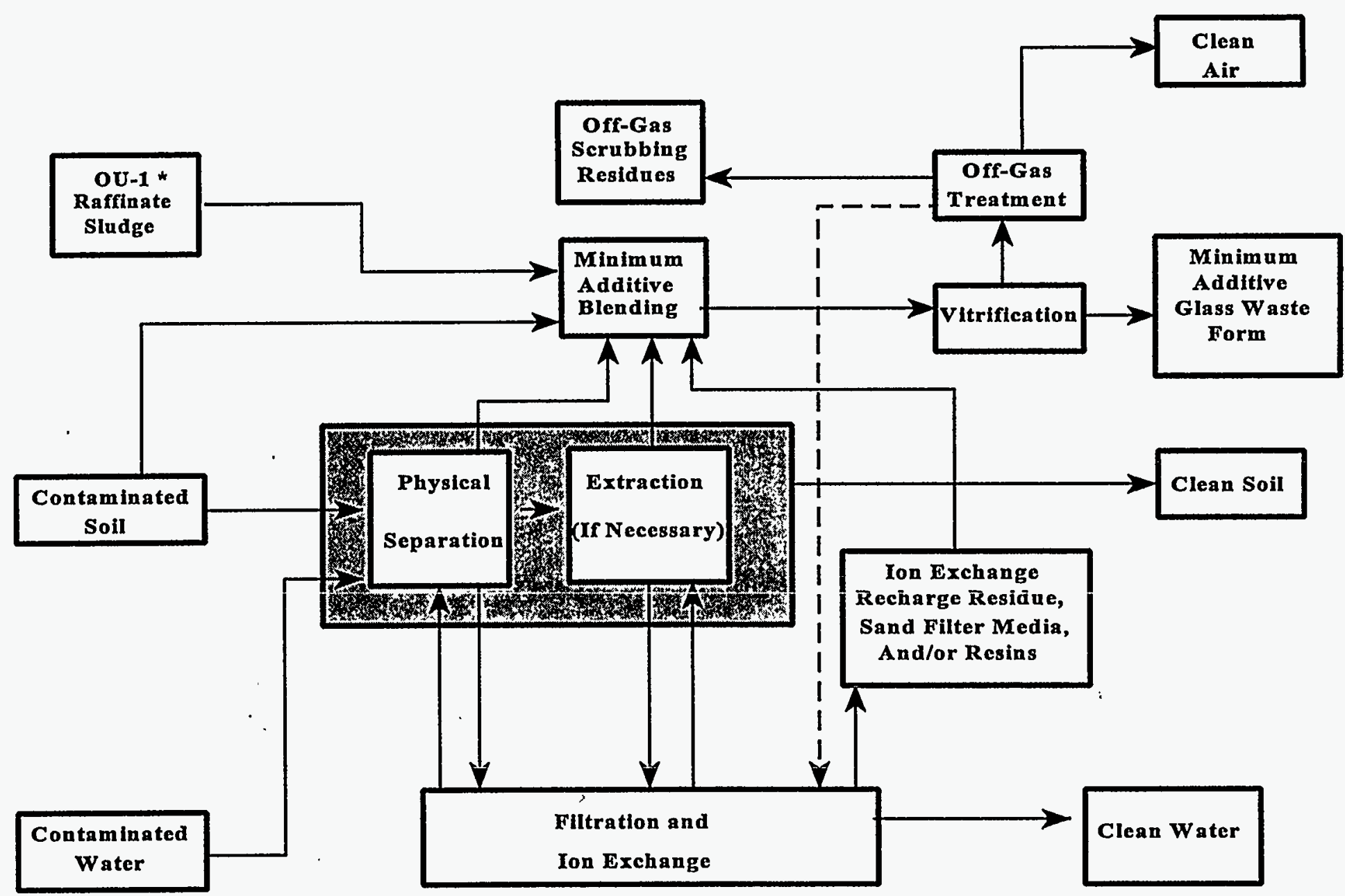

* The FEMP is divided into five operable units (OUs) to facilitate remediation. OU -1 consists of the Waste Pits 1-6, the Clearwell, and the Burn Pit. 


\section{METHODOLOGY}

\section{Preliminary Research}

The following soil washing treatability test conclusions were based on the findings of work on FEMP samples by the LESAT Technology Applications Division. These summarized test conclusions supplemented the basic research incorporated in the design considerations and flow diagram.

- The majority of Plant 1 pad soil samples were in the -325 mesh ( -44 micron) fraction, and all soil fractions evaluated were above the $35 \mathrm{pCi} / \mathrm{g}$ limit, as shown in Table 1.

- When a sample slurry was agitated and size separated, the suspended fraction consisted of most of the organic matter, clay, silt, and fine sand. The coarse materials remained at the bottom of the tank (referred to as the bottom fraction). Table 2 shows the size distribution of both fractions. Of particular note was the large fraction of vegetative organic matter. This fraction had an organic carbon content of over 25 percent.

Table 1. Soil Size Distribution and Activity of Fernald Plant 1 Pad Soils

\begin{tabular}{||r|r|r|r|r||}
\hline & & \multicolumn{2}{|c|}{ Activity } \\
\hline Size Fraction & Weight, lb & $\begin{array}{r}\text { Weight } \\
\text { Percent }\end{array}$ & pCi/g & Percent \\
\hline+10 mesh (+2 mm) & 29.30 & 2.77 & 291.60 & 1.13 \\
\hline+20 mesh (840 micron) & 35.10 & 3.31 & 477.30 & 2.23 \\
\hline+50 mesh (297 micron) & 44.80 & 4.23 & 426.70 & 2.54 \\
\hline+100 mesh (149 micron) & 37.20 & 3.51 & 1628.60 & 8.05 \\
\hline+200 mesh (74 micron) & 35.70 & 3.37 & 1909.50 & 9.05 \\
\hline+325 mesh (44 micron) & 47.20 & 4.46 & 884.20 & 5.54 \\
\hline-325 mesh (-44 micron) & 829.60 & 78.35 & 648.50 & 71.46 \\
\hline Totals & 1058.90 & 100.00 & & 100.00 \\
\hline & & & 895.20 & \\
\hline \hline
\end{tabular}


Table 2. Soil Size Distribution after Delumping

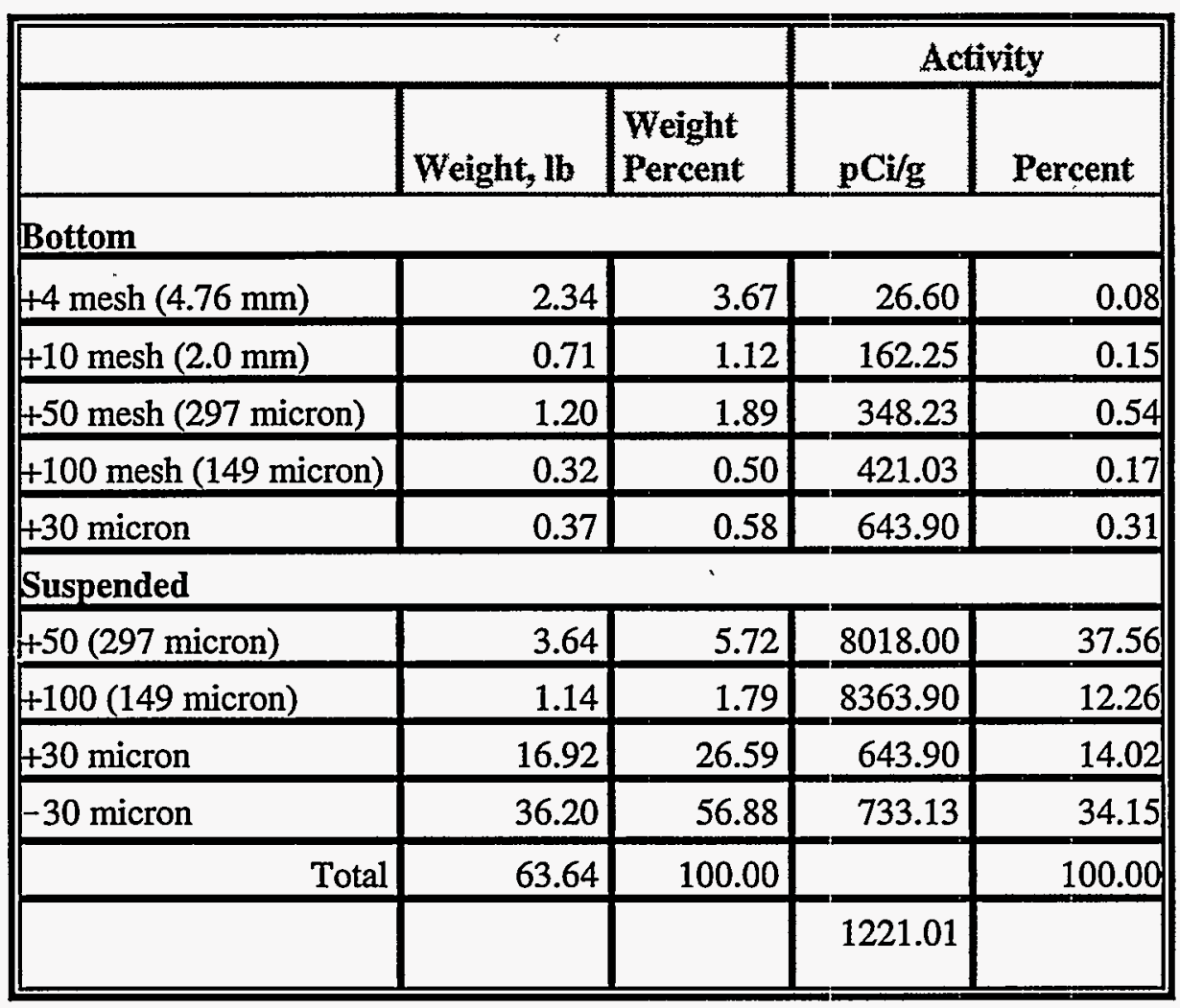

- The -100 mesh and +30 micron fraction were found to have the highest silica content. The average silica content in this fraction was approximately 71 percent. The coarse sands (the +20 mesh fraction) achieved the $35 \mathrm{pCi} / \mathrm{g}$ criterion after the organic matter was removed by dilution, scrubbing, and decanting. For all other fractions, physical separation techniques alone were not sufficient to meet the criterion.

- Most of the organic matter of -20 mesh and +100 mesh material could be stripped off the soil particles by agitation and scrubbing and could be removed effectively from the slurry with the 50 and 100 mesh screens. The organic matter so separated contained a high level of activity relative to the other soil fractions; it was leachable but required significantly higher chemical usage, particularly of oxidant.

- Carbonate leaching of the -30 micron fraction followed by washing was effective in achieving the $35 \mathrm{pCi} / \mathrm{g}$ criterion at a temperature of $40^{\circ} \mathrm{C}$.

- The anion-exchange resin successfully removed the dissolved uranium from the leachate, allowing the barren water to be recycled for use in the soil washing system.

- The system is a net water user because a wet slurry feed is produced for vitrification. Therefore, even with water recycling, fresh water is needed to make up the difference. 


\section{Design Considerations and Flow Diagram}

Based on the above test conclusions, the process flow diagram (Figure 2) was developed by LESAT. The following were the major considerations.

Because the majority of the soil particles ( 85 percent by weight) were -325 mesh, only the +20 mesh material, after the organic matter had been removed, achieved the lower than $35 \mathrm{pCi} / \mathrm{g}$ limit by the physical separation technique. However, the volume reduction by physical separation alone would be low indeed. To increase the waste volume reduction, the fine fraction, which was the majority of the soil, would have to be treated chemically.

Because vitrification required good-quality silica sands as raw material and because the -100 mesh and +30 micron fraction had the highest silica content ( 71 percent), the design called for the removal of this fraction from the -30 micron fraction to be fed as raw material for vitrification.

Processing the organic matter would cost more than processing the soil fraction because more reagent would be required. Vitrification performed by the Vitreous State Laboratory indicated that the organic matter was acceptable for vitrification. Therefore, the design called for separation of the organic matter to be sent to the melter.

After coarse sands and organic matter were removed, the bulk of the contaminated soil was -30 micron fines. They would be treated with leaching chemicals at elevated temperatures to dissolve the uranium compounds, reducing the activity to below $35 \mathrm{pCi} / \mathrm{g}$.

Among the proven technologies in uranium hydrometallurgy, there are two major leaching processes for uranium extraction: sulfuric acid leach and carbonate leach. A sulfuric acid leach results in the dissolution of elements and compounds besides uranium and presents problems such as impure solution and corrosion, while a carbonate leach is more selective in dissolving uranium and has fewer potential corrosion and safety concerns. As the objective of soil remediation specifies removal of uranium selectively from the contaminated soil without seriously degrading the physicochemical characteristics of the soils, carbonate leach does have the advantage. Furthermore, it produces waste streams that are less difficult to manage and dispose of. Therefore, after laboratory verification, carbonate leach was selected.

Oxidized uranium minerals are normally dissolved in carbonate-bicarbonate media. Tetravalent uranium, however, is not dissolved until it is oxidized. For contaminated soil from FEMP, this was the case. In theory, the reaction can be expressed as

$$
2 \mathrm{UO}_{2}+\mathrm{O}_{2}+6 \mathrm{Na}_{2} \mathrm{CO}_{3}+2 \mathrm{H}_{2} \mathrm{O} \rightarrow 2 \mathrm{Na}_{4} \mathrm{UO}_{2}\left(\mathrm{CO}_{3}\right)_{3}+4 \mathrm{NaOH}
$$


Figure 2 - Schematic Flow Diagram of

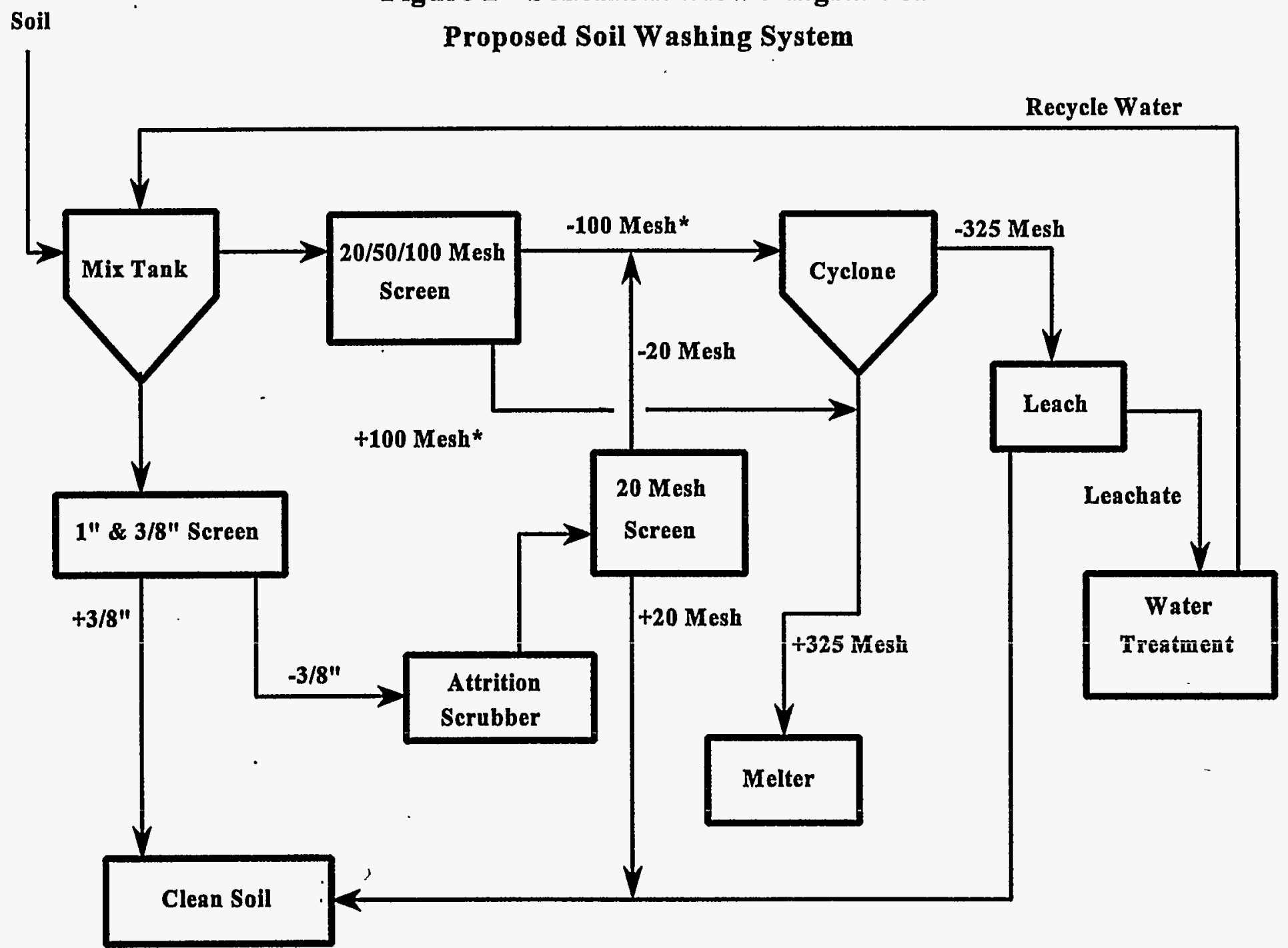

* In the demonstration testing the 100 mesh screen was removed. 
In practice, however, the results are not entirely satisfactory. Because caustic soda (NaOH) is generated, the above reaction attacks and decomposes the complex ion just formed and returns uranium to solid form as sodium diuranate. It is a premature precipitation, expressed as

$$
2 \mathrm{Na}_{4} \mathrm{UO}_{2}\left(\mathrm{CO}_{3}\right)_{3}+6 \mathrm{NaOH} \rightarrow \mathrm{Na}_{2} \mathrm{U}_{2} \mathrm{O}_{7} \downarrow+6 \mathrm{Na}_{2} \mathrm{CO}_{3}+3 \mathrm{H}_{2} \mathrm{O}
$$

This problem of premature precipitation is solved by adding bicarbonate, sodium bicarbonate, or ammonium bicarbonate, as shown below, to neutralize the caustic soda as soon as it forms.

$$
\begin{gathered}
\mathrm{NaHCO}_{3}+\mathrm{NaOH} \rightarrow \mathrm{Na}_{2} \mathrm{CO}_{3}+\mathrm{H}_{2} \mathrm{O} \\
2 \mathrm{NH}_{4} \mathrm{HCO}_{3}+2 \mathrm{NaOH} \rightarrow \mathrm{Na}_{2} \mathrm{CO}_{3}+\left(\mathrm{NH}_{4}\right)_{2} \mathrm{CO}_{3}+2 \mathrm{H}_{2} \mathrm{O}
\end{gathered}
$$

Multiple stages of thickeners and filters are commonly used to recover leachate from leached slurry for downstream processing and to serve as a washing system. However, these stages require a large amount of floor space and more supporting equipment while, generally, operating without an enclosure. Therefore, for the MAWS demonstration, a centrifugation system was selected for washing and dewatering.

\section{System Description and Process Parameters}

The soil washing-leaching system consists of three basic subsystems, which perform physical separation, leaching, and dewatering.

\section{Physical Separation System}

The system performs size separation functions with vibrating screens and cyclones in two steps, as follows.

Soil Slurrying. A heavy-duty mixer is used to slurry the contaminated soil, to break up the lumps, and to separate rocks from organic matter such as grass, roots, leaves, and small branches. With the addition of recycled water, the mixer prepares a slurry of 32-36 percent solids. Because additional water is required to keep the passage open through the drain valve during the transfer step, the percent of solids is $26-32$ percent as delivered to the screening stage. The system operates in batches, with each charge consisting of three 55-gallon drums of contaminated soils, or about $1300 \mathrm{lb}$ of dry soils.

Screening and Cycloning. After 30 minutes of mixing, the slurry is ready for size separation and is pumped to a 24-inch, enclosed vibrating screen set of 20 mesh and 50 mesh. The original design, which called for 100 mesh, was changed as a tradeoff to speed up the screening and to increase the load to the downstream hydrocyclones. The coarse material (mainly rocks, gravel, and coarse sand) in the mixer after the slurry has been pumped out is transferred by a screw conveyor and screened through a 3/8-inch screen. The oversize is rinsed, verified, and retained in drums to be returned to FEMP. The less than 3/8inch material is fed to an attrition scrubber followed by vibrating screens of 20 mesh and 50 mesh. 
The undersizes of both sets of vibrating screens become the feed to the hydocyclones. The oversizes are the silica sands and organic matter, which are fed to the melter for vitrification. The overflow of the hydrocyclones is the leach feed, while the underflow, collected in drums, joins the oversizes from the first set of screens as feed for vitrification (see Figure 2).

\section{Leaching System}

The leaching system comprises a leach feed tank located on the lower deck of the physical separation skid and six leach tanks set on the leach skid for gravity flow. The feed slurry is pumped at 6 to 10 gallons per minute to leach tank No. 1 and flows, by gravity, through the circuit with a retention time of about 6 hours. Sodium carbonate, ammonium bicarbonate, and potassium permanganate are the reagents for the chemical treatment of the soils. They are added to tank No. 1 by automatic control with a pH target of 8.5 to 9.5 and an EMF target of -550 to $-520 \mathrm{mv}$.

For oxidation of uranium, potassium permanganate is a powerful oxidizing agent, which oxidizes uranium to the hexavalent state so that the uranium can be dissolved in a carbonate medium in an atmospheric system. Also, it is necessary to maintain oxidizing conditions all through the leaching and washing processes to prevent reduction of the dissolved hexavalent uranium by reducing agents originally present in the soils. The oxidation reaction is

$$
3 \mathrm{UO}_{2}+2 \mathrm{MnO}_{4}^{-1}+9 \mathrm{CO}_{3}^{-2}+4 \mathrm{H}_{2} \mathrm{O} \rightarrow 3 \mathrm{UO}_{2}\left(\mathrm{CO}_{3}^{-2}\right)_{3}^{-4}+2 \mathrm{MnO}_{2}+8 \mathrm{OH}^{-1}
$$

Ammonium bicarbonate is required to keep dissolved uranium in solution, because in the absence of bicarbonate, uranium will precipitate as sodium uranate. This precipitate results from the increase of hydroxide from the reactions. The process is represented as follows:

Uranium oxide is dissolved as carbonate

$$
\mathrm{UO}_{3}+3 \mathrm{Na}_{2} \mathrm{CO}_{3}+\mathrm{H}_{2} \mathrm{O} \rightarrow \mathrm{Na}_{4} \mathrm{UO}_{2}\left(\mathrm{CO}_{3}\right)_{3}+2 \mathrm{NaOH}
$$

Uranate precipitates in the absence of bicarbonate $2 \mathrm{Na}_{4} \mathrm{UO}_{2}\left(\mathrm{CO}_{3}\right)_{3}+6 \mathrm{NaOH} \rightarrow \mathrm{Na}_{2} \mathrm{U}_{2} \mathrm{O}_{7} \downarrow+6 \mathrm{Na}_{2} \mathrm{CO}_{3}+3 \mathrm{H}_{2} \mathrm{O}$

Bicarbonate reacts with hydroxide

$$
2 \mathrm{NH}_{4} \mathrm{HCO}_{3}+2 \mathrm{NaOH} \rightarrow \mathrm{Na}_{2} \mathrm{CO}_{3}+\left(\mathrm{NH}_{4}\right)_{2} \mathrm{CO}_{3}+2 \mathrm{H}_{2} \mathrm{O}
$$

\section{Centrifuge Dewatering System}

For washing and dewatering, three centrifuges and their auxiliary equipment were installed on the centrifuge skid.

From the leach skid, a centrifuge feed pump advances leached slurry to the No. 1 centrifuge. Flocculent is added to the first two units to assist the solid-liquid separation. The underflow of the third unit is the washed product and is discharged into steel drums to be verified as clean soil. 


\section{Instrumentation}

The soil washing system includes instruments that control process conditions and maintain solution balances. They are standard instruments commonly used in the chemical process industry.

The instruments measure $\mathrm{pH}, \mathrm{EMF}$, temperature, tank level, density, and flow rates. For temperature, tank level, density, and flow rates, feedback control loops maintain preset conditions.

A piping and instrumentation drawing of the whole soil washing system is provided in Appendix A.

\section{PLANT OPERATION}

\section{Standard Operating Procedure}

A complete set of standard operating procedures (SOPs) was prepared before the startup of the soil washing and soil leaching system. The SOPs included the procedures shown in Table 3.

The following guidelines were used in preparing the SOPs:

1. Each procedure is in full compliance with LESAT quality assurance/quality control policies.

2. Each procedure describes the purpose of the standard practice and record keeping to ensure accountability of the operation.

3. Each procedure defines its applicability and the conditions under which it is intended to be followed.

4. Each procedure includes the general description of tasks involved and the feature and function of the equipment.

5. Each procedure defines the terms and parts used.

6. Each procedure defines the responsibility of each person involved in the task and the associated records to be kept.

7. Each procedure describes the steps to perform the task in logical order with sufficient detail and clarity.

8. Each procedure follows the equipment manufacturer's recommendations in installation, calibration, operation, and maintenance as well as tools to be used.

9. Each procedure includes routine and nonroutine auditing procedures for total quality control and management. 
10. Each procedure emphasizes environmental, health, and safety requirements; personal responsibility; and teamwork.

11. Each procedure details the documentation requirement for accountability and review.

12. Each procedure includes the essential references.

13. Each procedure provides the standard forms for record, drawing, and process flowsheets in the attachment.

14. Each procedure is to be updated with management review and approval as an essential part of change management.

It was not intended that the SOP cover every situation that could arise, and the use of the SOP does not relieve operating personnel of their responsibility to comply with safe practices and use good judgment.

The SOP also emphasizes, for all personnel, the function to see that each piece of equipment operates satisfactorily so that the MAWS system performs as required. Additionally, the SOP was reviewed, in its operational aspects, by FERMCO.

Table 3. Standard Operating Procedures

\begin{tabular}{|c|c|c|c|c|}
\hline \multirow{2}{*}{ SOP No. } & \multirow[b]{2}{*}{ Title } & \multirow[b]{2}{*}{ Revision } & \multicolumn{2}{|c|}{ Effective } \\
\hline & & & Chg. & Date \\
\hline MAW-201 & Physical Separation System & 1 & & $11 / 2 / 93$ \\
\hline MAW-301 & Leach System & 1 & & $11 / 2 / 93$ \\
\hline MAW-302 & Centrifuge Dewatering System & 1 & & $11 / 2 / 93$ \\
\hline MAW-401 & $\begin{array}{l}\text { Sample Receipt, Logging, and Chain-of- } \\
\text { Custody }\end{array}$ & 1 & & $9 / 15 / 93$ \\
\hline MAW-402 & $\begin{array}{l}\text { MAWS Laboratory Sample Receipt, Logging, } \\
\text { and Chain-of-Custody }\end{array}$ & 0 & & $9 / 15 / 93$ \\
\hline MAW-501 & Sampling & 1 & & $11 / 2 / 93$ \\
\hline MAW-601 & Extended Shut-Down Preparation & 0 & & $11 / 2 / 93$ \\
\hline
\end{tabular}




\section{System Startup Sequence}

\section{Readiness Review}

In preparation for system startup, LESAT followed FERMCO's systematic and documented review process and conducted a readiness review to ensure that the MAWS system was ready to begin processing radioactive contaminated soil at FEMP's Plant 9. The LESAT readiness review procedure incorporated the format and checklist items from the FERMCO Readiness Review Process document SSOP-0100, dated January 15, 1993.

A final report was issued after all items had been satisfied and verified, and permission was given for initiation of clean soils tests on October 1, 1993.

\section{Clean Soil Plant Test}

The clean soils tests were conducted during October 1993. They served to commission the soil washing and leaching system. Nonradioactive material was used for the tests because of the high probability of spillage or leaks during the initial system checkout.

The goals were to ensure that each component performed satisfactorily and that each operator understood the soil washing and leaching processes as well as each step of the operation assigned. No attempt was made to run the clean soil in a continuous mode. The focus was on training operations personnel. The whole system was decoupled and divided into five working areas, each manned by one operator:

- mixing and slurry pumping,

- screening,

- leaching,

- washing, and

- utility.

The test was conducted component by component throughout the system, and each operating procedure was followed and repeated when necessary until each operator clearly understood the function, the operation, and the control of each piece of equipment of the area assigned.

Kilborn Engineering assisted in commissioning the plant and in conducting the clean soil test following the Lockheed Environmental Systems and Technologies Commissioning Procedure. The goals of the commissioning were the following.

1. Ensure all ancillary services (air, water, sewer, and water treatment) perform satisfactorily. Familiarize operating staff with loading and removal of soil in drums. 
2. Ensure the flow control systems (based on flow meters, tank level sensors, and auto control valves) maintain even flow throughout the entire system with both water and slurry.

3. Ensure mechanical soundness of all equipment while operating with slurry/solids.

4. Ensure that slurry handling in all pipelines occurs without blockage at the design water/solids (W/S) ratios and flow rates.

5. Ensure that process criteria relating to physical (size) separation can be met at the design W/S ratios and flow rates.

6. Ensure that process criteria relating to centrifuge dewatering are met.

7. Familiarize operating staff with sampling and quality control procedures and ensure that representative samples can be taken as outlined in the operating procedures.

The test continued with instrument and equipment adjustment and repair and was completed after the system cleanup on October 7, following implementation of the extended shutdown procedure. The ventilation system of Plant 9 required further adjustment by FERMCO, so the soil washing system remained shut down during the adjustment period. During the test, the water treatment system could not sustain processing water for recycle due to shortcycling. Adjustments are necessary to optimize this critical interface. 


\section{RESULTS}

Soil washing of radioactively contaminated soils began in December 1993 . The following is a review of the operations.

\section{Physical Separation System}

\section{Soil Loading and Slurrying}

The mixer was operated on a batch basis. Water was added, by filling to a marked level, to achieve a 32-36 percent solids slurry. One batch consisted of three 55-gallon drums of soil and approximately 320 gallons of water, filling the mixer to a capacity of 1.8 to 2.0 cubic yards. Slurry density was checked periodically with the Marcy density scale. After thorough delumping and mixing, the slurry with organic matter was withdrawn from the mixer by draining through the drain valve, while the coarse material settled to the bottom of the mixer.

The system did not perform as well as expected. The drain valve required additional water injection to keep the passage open, and the slurry was therefore further diluted and was transferred by the sump pump to the vibrating screens and hydrocyclones for size separation.

For the soil washing system, slurry transfer from the mixer to the screening and cycloning stage was the slowest step of the operation. It was the bottleneck, in terms of cubic yards of input soil per hour. This bottleneck, together with the "short cycle" problem of the filtration system of the waste water treatment, greatly limited the overall performance of the soil washing system. Thus, system operation was reduced to a semibatch process.

From the operation record, the throughput was not as consistent as expected. There were periods, as the situation was improving towards the end of the demonstration, when both the soil washing system and the waste water treatment system were online, and the throughput was higher than three drums of contaminated soils for 2.5 hours, a rate that was equivalent to 0.25 cubic yards per hour. The rate still averaged three drums per batch, but a shorter time was required to accomplish the task.

\section{Screening and Cycloning}

The vibrating screens were effective in removing +50 mesh material, including organic matter. Minor blinding of the screens was experienced, which required shutting off the feed slurry temporarily and applying water spray to clear the screens. Because of the replacement of the 100 mesh screens with 50 mesh screens, the load to the hydrocyclones increased.

Size separation with hydrocyclones is not as clear-cut as screening; the extra load to the hydrocyclones resulted in larger amount of the coarser material being directed to the overflow, which increased the total amount of leach feed. 
It was proven in the laboratory leaching test and in this demonstration that coarser sands were easier to leach and easier to decontaminate, and the overall volume reduction was enhanced with the addition of the coarser fraction to the leach feed.

\section{Coarse Material}

The coarse material was withdrawn by raising one end of the mixer hydraulically and opening a hydraulically controlled gate at the end of the mixer. The paddles were angled such that, if slowly rotated, they pushed the coarse materials toward the open gate. The coarse materials were rinsed along the screw conveyor. Large amounts of water were required.

The scalping screens, the scrubber, and the vibrating 18- and 24-inch screens could process more material than they were required to in this demonstration.

\section{Leaching System}

The average feed to the soil washing process had a uranium assay of $26 \mathrm{ppm}(\sim 17.6 \mathrm{pCi} / \mathrm{g})$. The clean soil had an average assay of $9 \mathrm{ppm}(6.1 \mathrm{pCi} / \mathrm{g})$. The uranium content of the contaminated soils provided for processing was much lower than that of the samples on which the design of the soil washing system was based.

\section{Centrifuge Dewatering System}

For washing and dewatering, the three centrifuges were a modified countercurrent system operating at high wash ratio, as they were designed. (The wash ratio is defined in this configuration as the ratio of the volume of the centrate to the volume of solution with the discharged solids.) The No.1 centrifuge serves as a dewatering device in series with a two-stage countercurrent decantation system. The centrates of the No. 1 and No. 2 centrifuges make up the feed solution to the waste treatment system. For this special system the wash ratio was 9.5 gallons per minute to 1.2 gallons per minute, or about 8 to 1 . 


\section{CONCLUSIONS}

\section{System Output}

On April 16, after batch 70, the feed stopped. Since December 14, 1993, a total of 209 drums had been fed to the soil washing system (three drums per batch, except batch 41 , which had only two drums). The system continued to clean out the in-process material, and shutdown occurred on April 28, 1994, after the last drum of clean soil was packaged.

Table 4 shows production data by week. In summary, the totals are

- $\quad 91,134 \mathrm{lb}$ dry contaminated soil processed,

- $\quad 50,716 \mathrm{lb}$ of clean soil produced through leaching and washing,

- $6478 \mathrm{lb}$ of clean rocks and gravel,

- $\quad 3384 \mathrm{lb}$ of clean fines from cleanup,

- $\quad 30,199 \mathrm{lb}$ of silica sands and organic matter were fed to vitrification, and

- $60,578 \mathrm{lb}$ of clean soils, with activity below $35 \mathrm{pCi} / \mathrm{g}$, were collected for a waste volume reduction of 66.5 percent.

\section{Lessons Learned}

\section{Advantage of Gravity Flow}

The physical separation operation was the most labor-intensive operation and was the bottleneck of the soil washing system. It required three operators, compared to one as originally assigned, to run the system. This problem could be solved by replacing the mixer and the conveyor with a rotating drum mixer, similar to a cement mixer, and with direct discharge to the scalping screen, attrition scrubber, and classification system. This configuration would require only two operators, would have no valve restriction and no transferring problem, and would take full advantage of gravity flow.

\section{Flexibility in Soil Washing}

The uranium content of the soil provided to process in this demonstration testing was lower than that of the soils provided for testing and generating the system design specification; it averaged only $20 \mathrm{ppm}$. There is no doubt that the contaminated soils of FEMP have a much wider range of uranium assays and characteristics. Acid leaching would provide greater flexibility in processing soils with such a wide range of uranium content. 
Table 4. Soil Distribution Summary

\begin{tabular}{|c|c|c|c|c|c|c|c|c|c|c|}
\hline \multirow{2}{*}{\multicolumn{4}{|c|}{$\begin{array}{l}\text { Feed to Soll Washing } \\
\text { (contaminated soil) }\end{array}$}} & \multirow{2}{*}{\multicolumn{3}{|c|}{ Clean Soil }} & \multicolumn{4}{|c|}{ Silica Sand to Melter } \\
\hline & & & & & & & \multicolumn{2}{|c|}{ Screen Oversize } & \multicolumn{2}{|c|}{ Cyclone Underflow } \\
\hline Week & $\begin{array}{l}\text { Dry } \\
\text { wt., lb }\end{array}$ & $\begin{array}{l}\text { Percent } \\
\text { Moisture }\end{array}$ & $\begin{array}{l}\text { Uranium, } \\
\text { lb }(\mathrm{pCi} g)^{a}\end{array}$ & $\begin{array}{l}\text { Dry } \\
\text { wt., } 1 \mathrm{~b}\end{array}$ & $\begin{array}{l}\text { Percent } \\
\text { Moisture }\end{array}$ & $\begin{array}{l}\text { Uranium, } \\
\text { lb (pCilg) }\end{array}$ & $\begin{array}{l}\text { Dry } \\
\text { wt, lb }\end{array}$ & $\begin{array}{l}\text { Percent } \\
\text { Moisture }\end{array}$ & $\begin{array}{l}\text { Dry } \\
\text { wh, lb }\end{array}$ & $\begin{array}{l}\text { Percent } \\
\text { Moisture }\end{array}$ \\
\hline 01 & 8508 & 15.0 & $0.045(3.6)$ & 0 & & & 742 & 50.1 & & \\
\hline 02 & 0 & & & 0 & & & 0 & & & \\
\hline 03 & 0 & & & 0 & & & 0 & & & \\
\hline 04 & 3123 & 17.5 & $0.042(9.1)$ & 484 & 37.6 & $0.00036(0.51)$ & 0 & & 132 & 60.0 \\
\hline 05 & 0 & & & 423 & 43.2 & $0(0)$ & 0 & & 210 & 47.9 \\
\hline 06 & 0 & & & 0 & & & 0 & & 0 & \\
\hline 07 & 2271 & 17.6 & $0.028(8.4)$ & 2083 & 38.8 & $0.0022(0.72)$ & 517 & 46.5 & 0 & \\
\hline 08 & 0 & & & 686 & 38.7 & $0(0)$ & 0 & & 0 & \\
\hline 09 & 5032 & 14.1 & $0.046(6.2)$ & 2773 & 35.3 & $0(0)$ & 771 & 49.0 & 915 & 47.6 \\
\hline 10 & 2583 & 12.3 & $0.027(7.1)$ & 2455 & 39.5 & $0(0)$ & 508 & 61.4 & 0 & \\
\hline 11 & 0 & & & 139 & 55.1 & $0.00156(7.6)$ & 0 & & 0 & \\
\hline 12 & 0 & & & 0 & & & 0 & & 0 & \\
\hline 13 & 10,714 & 10.9 & $0.486(31)$ & 5421 & 31.9 & $0.03462(4.3)$ & 1871 & 42.0 & 1503 & 45.4 \\
\hline 14 & 11,969 & 10.5 & $0.364(21)$ & 5520 & 40.7 & $0.05064(6.24)$ & 4782 & 55.8 & 1663 & 43.9 \\
\hline 15 & 13,422 & 11.4 & $0.467(24)$ & 7462 & 42.6 & $0.06923(6.31)$ & 2268 & 48.0 & 1446 & 40.8 \\
\hline 16 & 13,577 & 12.3 & $0.823(41)$ & 7402 & 40.5 & $0.10493(9.64)$ & 2521 & 43.5 & 1510 & 38.25 \\
\hline 17 & 1404 & 2.0 & $0.029(14)$ & 5996 & 41.0 & $0.07420(8.42)$ & 223 & 54.3 & 613 & 61.2 \\
\hline 18 & 18,531 & 12.6 & & 5302 & 45.9 & $0.07180(9.21)$ & 3405 & 43.7 & 3839 & 64.6 \\
\hline 19 & 0 & & & 3740 & 47.9 & $0.04579(8.33)$ & 367 & 30.7 & 132 & 69.6 \\
\hline 20 & 0 & & & 830 & 47.0 & $0.00834(6.84)$ & 0 & & 261 & 80.7 \\
\hline Total & 91,134 & & 2.357 & $50,716^{6}$ & & 0.457 & 17975 & & 12,224 & \\
\hline Average & & 12.4 & $25.9(17.6)$ & & 41.1 & $9.0(6.1)$ & & 47.7 & & 54.5 \\
\hline
\end{tabular}


3. Simplification of Design and Operation

From the results of the demonstration testing of the soil washing and waste water treatment system, it is clear that until filtration of the leachate is improved, the water treatment process will continue to lag behind and overall efficiency will be diminished. One possible improvement would be to replace the fixed-bed ion-exchange system and sand filter with a well-proven technology of resin-in-pulp, which is an ion-exchange process in which resins are directly mixed with the leach slurry without separating the leachate from the solids first. While it eliminates the troublesome steps of solids-liquid separation and filtration, it also has been proven that the washing process can be minimized in the same operation. This proven technology is applicable for large-scale operations processing 100-200 tons of contaminated soil per hour.

4. Improvement of Hydrocyclone Performance and Volume Reduction

In this demonstration testing, the hydrocyclone experienced occasional plugging that resulted from the combination of organic matter and coarse sand entering the apex. Feed dilution is the most effective way of control. Though the additional water for dilution will result in a finer and sharper separation, it is not altogether desirable, as the downstream leaching and washing and waste water treatment will have to process the extra dilution. An adjustable apex will provide the flexibility not only to reduce the apex plugging but improve the control of the amount exiting as overflow and eventually as clean soils.

\section{Processing of Higher Assay Soil}

Because the uranium assays of the feed material provided were unexpectedly low, with an average of $20 \mathrm{ppm}$, during the testing, the ability of the soil washing system to extract contaminants at higher assays was not demonstrated. The laboratory tests conducted during the design of this system successfully processed soil samples from FEMP with uranium content to the level of $2000 \mathrm{ppm}$. However, successful processing of higher assay contaminated soil by the demonstration system, although reasonably expected, can only be assumed.

\section{Batch vs. Continuous Operation}

The demonstration testing was limited to about three months and was only conducted in the daytime of weekdays. When a bottleneck problem appeared, such as that of the filtration of the waste water treatment, it was not considered a "show-stopper," and the testing proceeded, haltingly. This fact, together with the constraint of the schedule, resulted in operation of the soil washing system as a batch process. The operating parameters, such as $\mathrm{pH}, \mathrm{EMF}$, and temperature, as well as the chemical consumption of the leaching circuit, were no longer those of a continuous process. The chemical cost per unit of the feed materials, as shown in Table 5, reflected the change from a continuous mode to the batch mode. 
In a continuous mixing tank, like the ones in the current leach circuit, the reaction rate basically depends on time, temperature, and reagent concentration. In this test, the minimum time was 5.5 hours in leaching, and the target temperature was set at $104^{\circ} \mathrm{F}$. The chemical reagents were controlled by $\mathrm{pH}$ and EMF; they were set as follows:

a. $\mathrm{pH}: 8.5-9.5$

At this level the carbonate was sufficient to react efficiently with the uranium compounds while not reacting much with other material. This level corresponded to 20 to 28 grams/liter of sodium carbonate at the outlet of the No. 1 leach tank. Ammonium bicarbonate was also added to prevent reprecipitation of the dissolved uranium through reaction of the hydroxide ion.

b. EMF: -520 to $-550(\mathrm{mv})$

The maintenance of adequate oxidizing potential is essential for dissolving uranium compounds and preventing reprecipitation caused by reversing of dissolution from reduction.

The decision of whether to run in batch or continuous mode is by no means insurmountable; proven solutions are available, as presented in this report.

Table 5. Chemical Consumption per Ton of Clean Soil Collected, for Continuous and Batch Modes

\begin{tabular}{|c|c|c|c|c|}
\hline \multicolumn{5}{|c|}{ Continuous Mode } \\
\hline & $\begin{array}{l}\text { Sodium } \\
\text { Carbonate }\end{array}$ & $\begin{array}{l}\text { Ammonium } \\
\text { Bicarbonate }\end{array}$ & $\begin{array}{l}\text { Potassium } \\
\text { Permanganate }\end{array}$ & Total \\
\hline Reagent, lb/ton & 50.9 & 37.9 & 24.2 & \\
\hline Unit price, $\$ /$ lb & 0.1125 & 0.37 & 1.425 & \\
\hline Cost, \$/ton & 5.73 & 14.02 & 34.49 & 54.24 \\
\hline \multicolumn{5}{|c|}{ Batch Mode } \\
\hline Reagent, lb/ton & 57.17 & 40.43 & 50.27 & \\
\hline Unit price, $\$ / / b$ & 0.1125 & 0.37 & 1.425 & \\
\hline Cost, \$/ton & 6.43 & 14.96 & 71.65 & 93.04 \\
\hline
\end{tabular}




\section{Reduction of Down Time}

In January and February 1994, a high percentage of slowdown or shutdown time was related to plugging of the sand filter and ion-exchange column of the waste water treatment system. In February the problem got worse when resin heads broke through the screen collectors of the ion-exchange column and were sent to the soil washing system. The problem was so persistent, and nonscheduled shutdowns resulting from filter back wash and repair so frequent, that the leaching and washing of the soil were no longer operating as a continuous system as designed. Additionally, the change to semibatch operation because of insufficient recycle water resulted in reduction of throughput, wasting manpower and chemicals.

The problem started with the excess turbidity in the leachate and the limited capacity of the filtration system. The waste water treatment provided recycle water for the soil washing system. Whenever the sand filter was off line for back wash or repair, it deprived the system of the waste water supply for soil washing. To use fresh water as a substitute was appropriate only for short-term relief. Any large quantity of fresh water input to the system would raise the inventory of water in the process while adding to the load on the sand filter before it could be discharged. This became a vicious circle that constantly aggravated short-cycle and shutdown problems. For a continuous leaching process, a leaching gradient can be established when a steady state is achieved. Oxidation and reduction potential (ORP) is an example. When reagent potassium permanganate was added to the No. 1 leach tank to the target ORP of $-520 \mathrm{mv}$ and when the slurry followed gravity and exited from the last leach tank (No. 6), its ORP arrived at the level of $-350 \mathrm{mv}$. When a system shutdown took place, there was no gravity flow from one tank to the next; therefore each tank retained its slurry. Often the ORP of a tank's contents drifted to below $200 \mathrm{mv}$, a level that is no longer sufficient in leaching uranium. When the system started again, additional reagent was required to finish the leaching. In late February 1994 additional surge capacity tanks were installed between soil washing and waste water treatment to improve solution clarification by increasing the settling area. The settled fines were then pumped back to soil washing. With this change, the situation improved: down time decreased and throughput increased.

\section{ACKNOWLEDGMENTS}

The preparers of this report thank many people for their contributions in helping gather the needed information, in reviewing the document during its draft stages, and in guiding its development. Jane Andrew and Nicholas Beskid of Argonne National Laboratory provided technical editing and consultation support for revising the figures and tables. Virginia Strezo and Maria Contos of Argonne provided valuable assistance with text processing and production coordination. 


\section{APPENDIX A.}

MASS BALANCE AND PIPING AND INSTRUMENTATION DIAGRAMS 
26 


\section{Mass Balance, Soil Washing System}
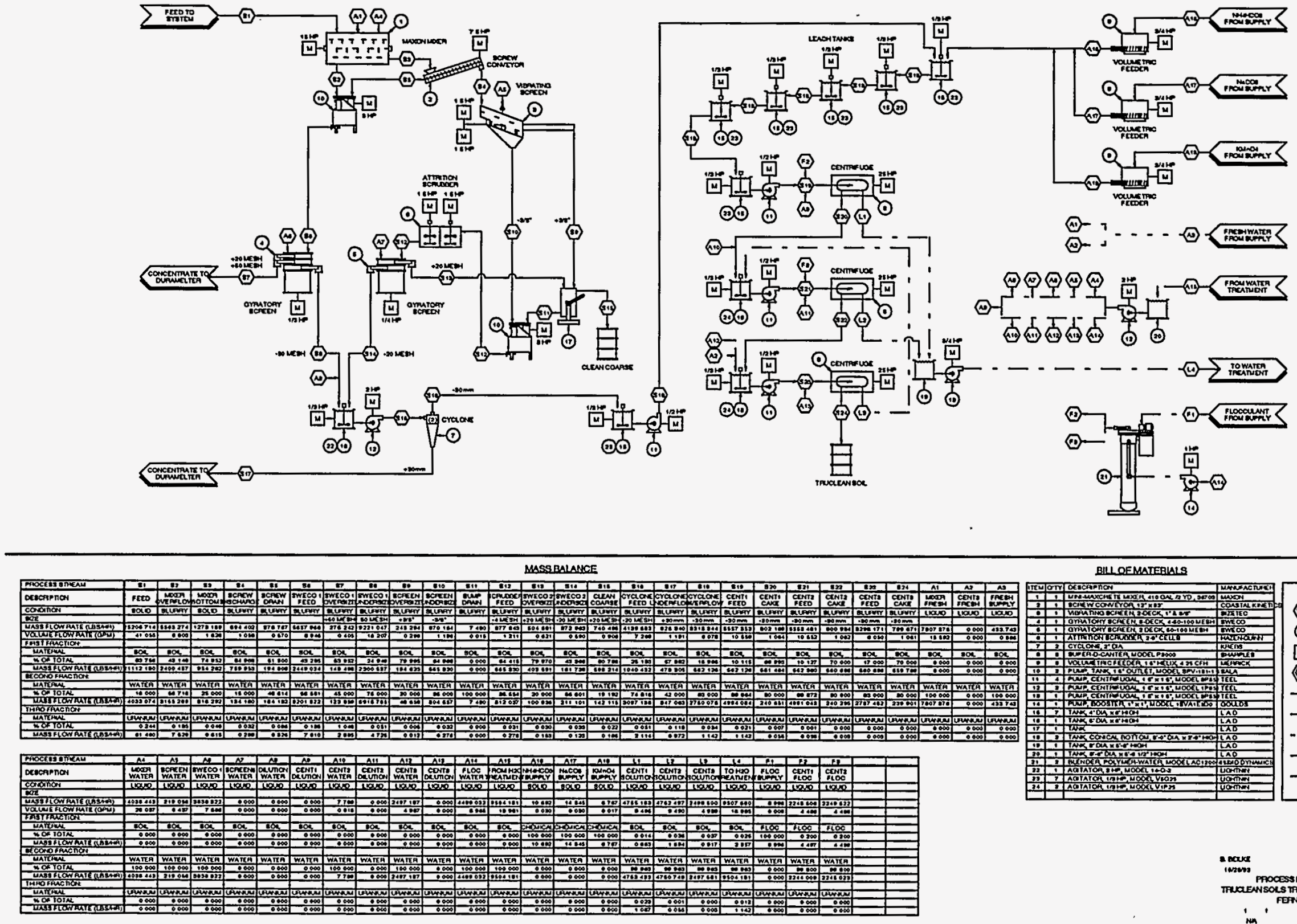

BHLOEMATEBILLS

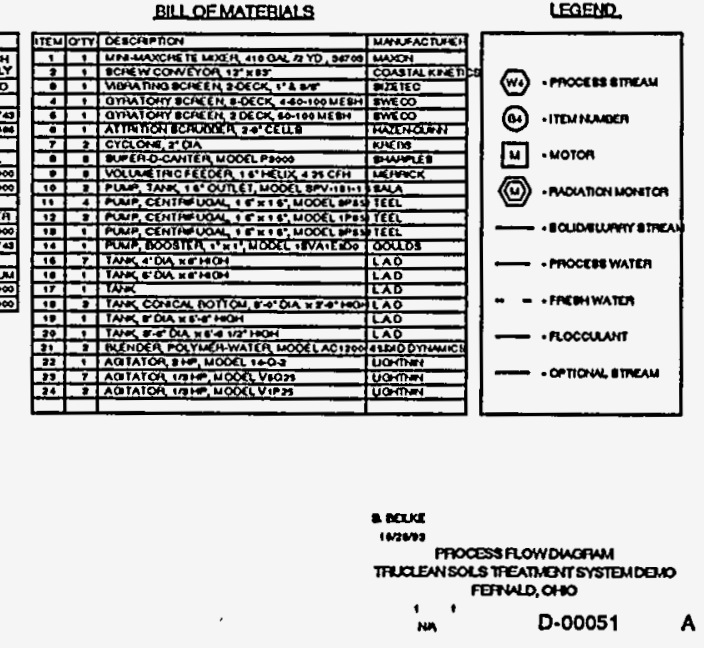




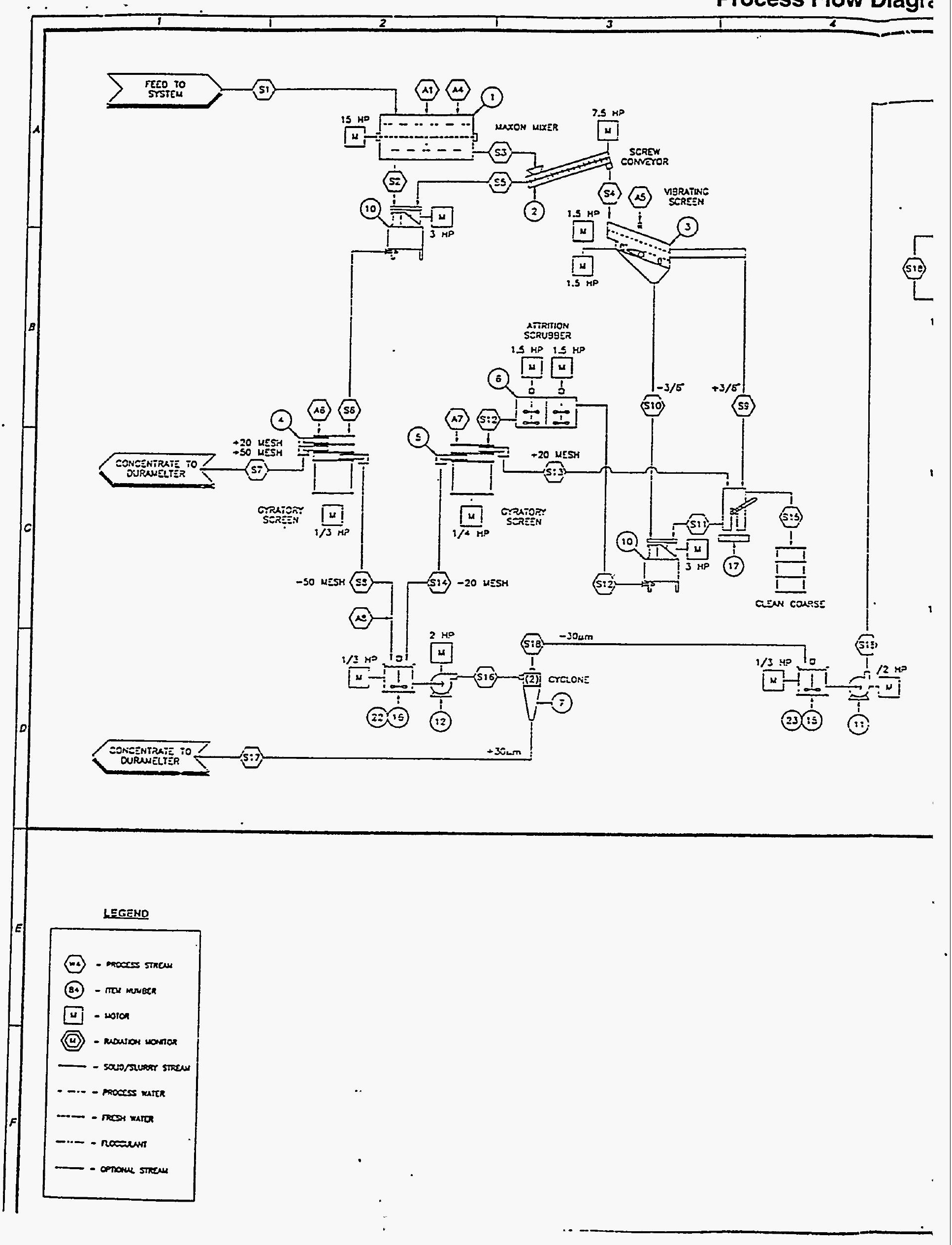




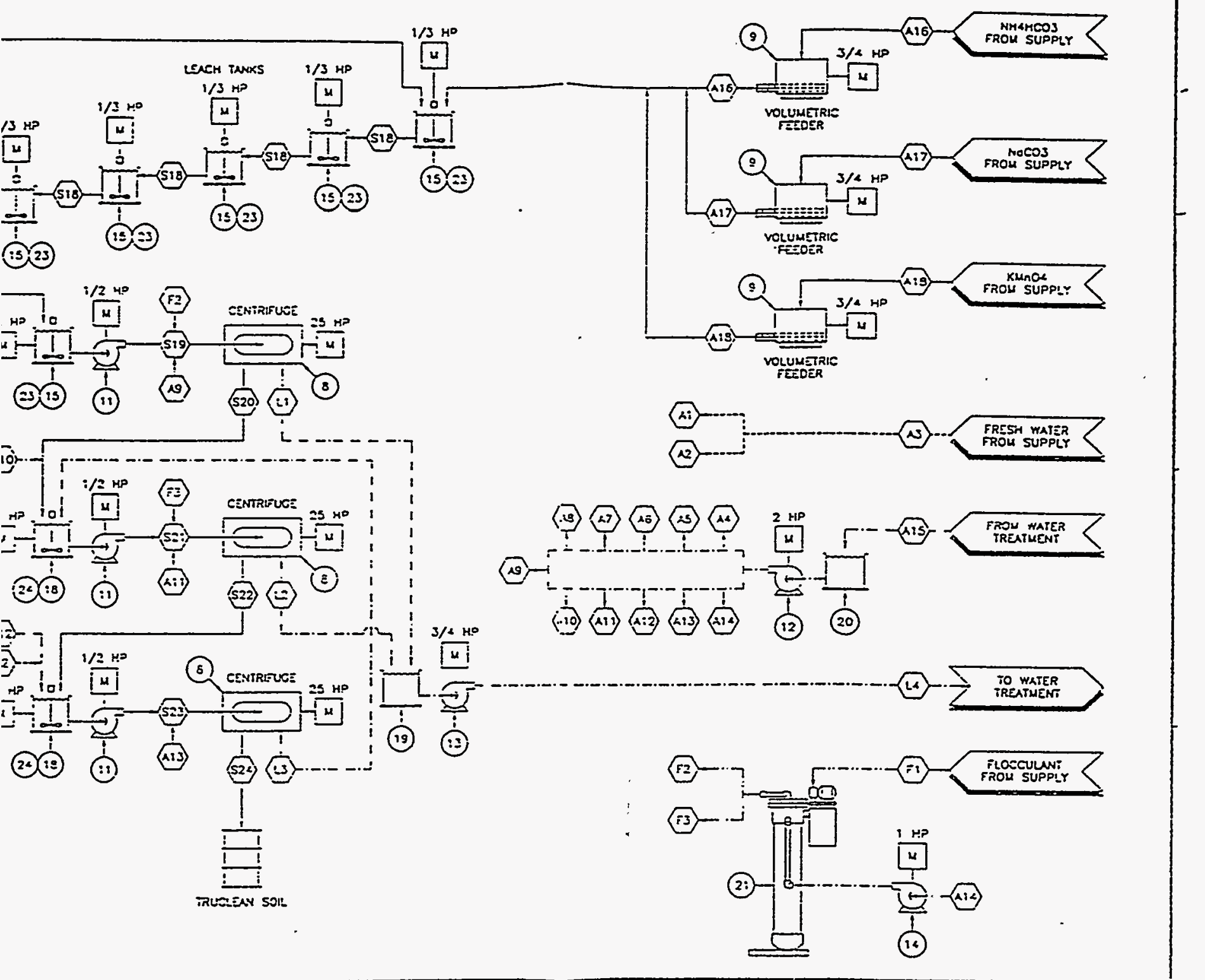


Piping and Instrume

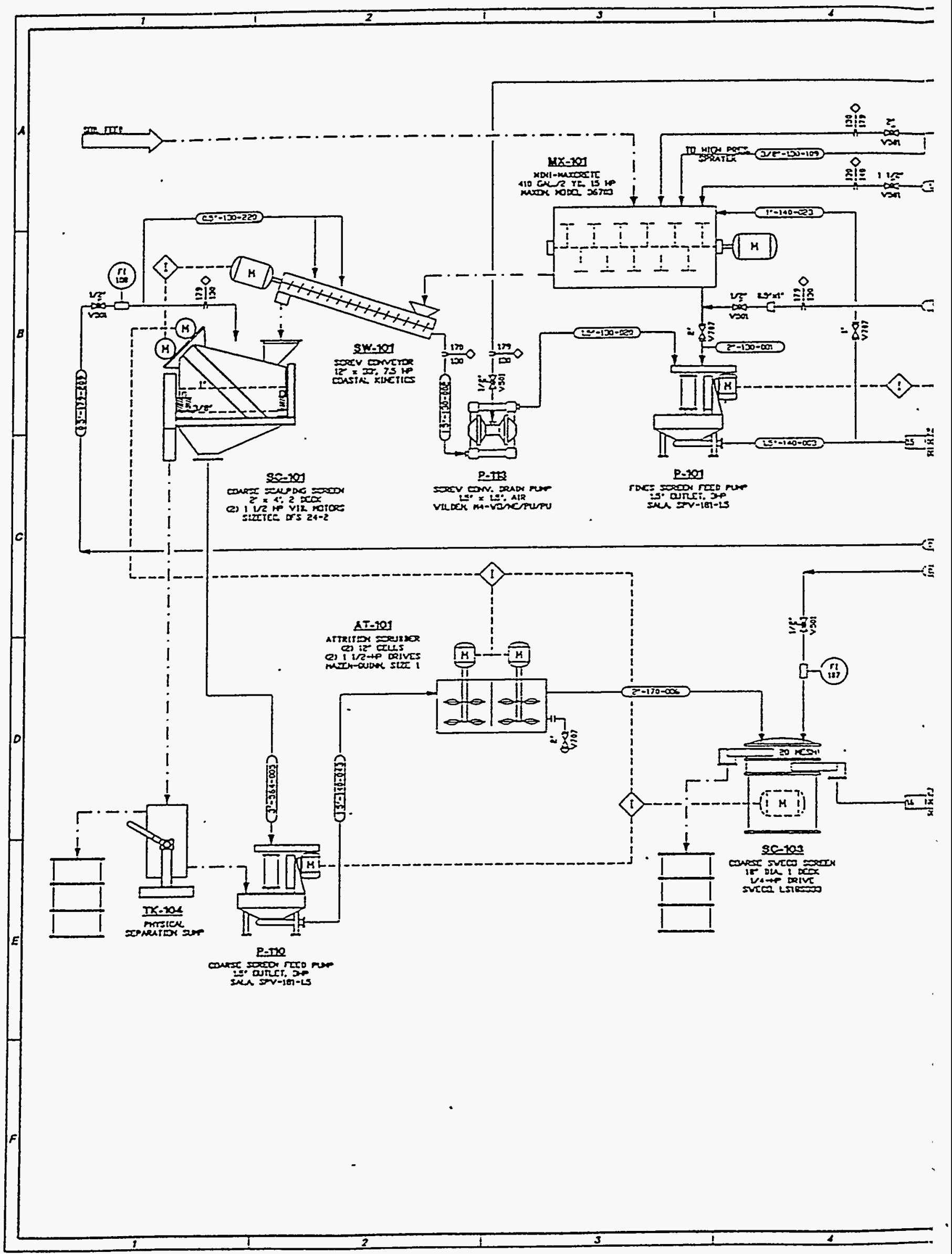


nentation, Diagram 2 of 4

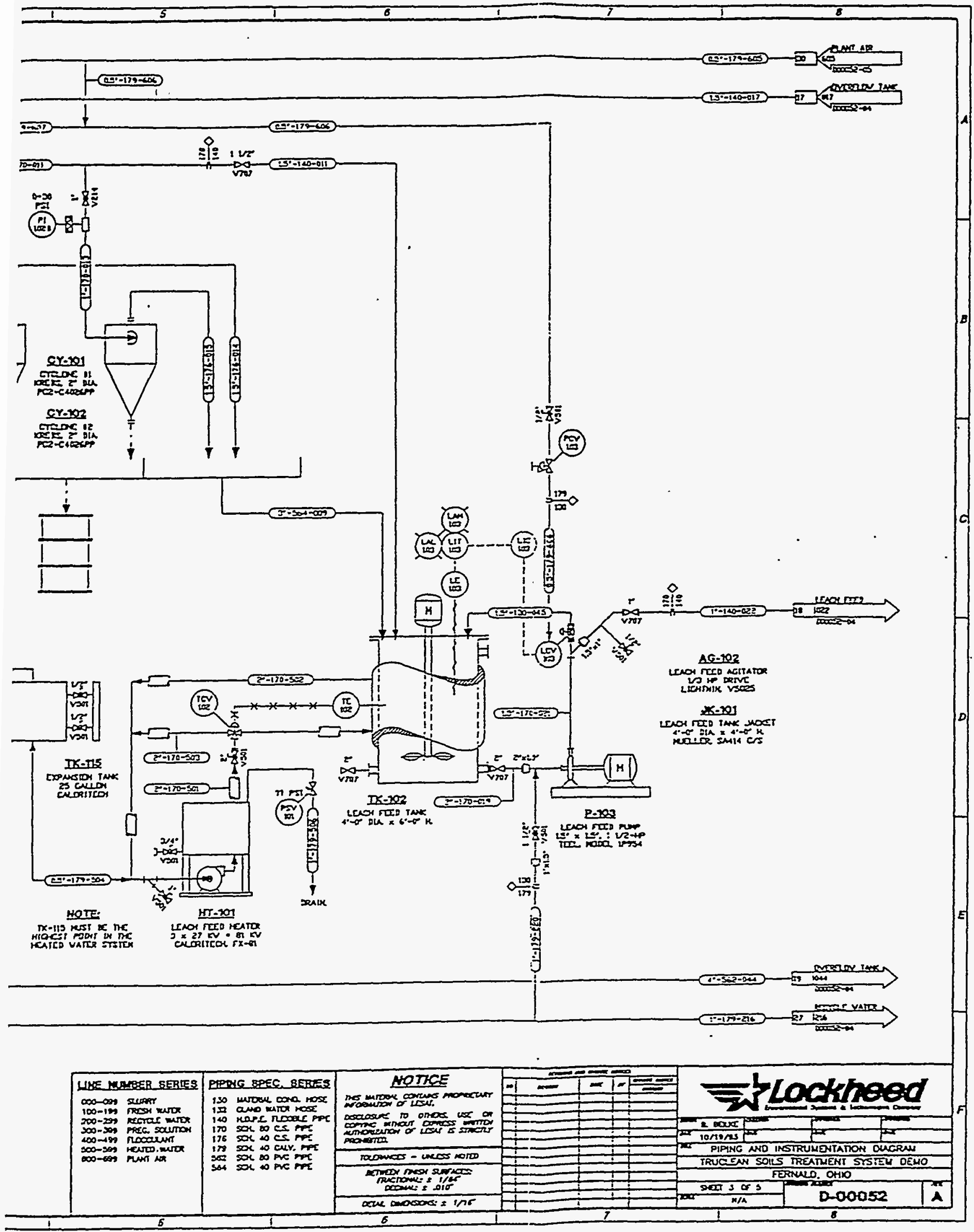


Piping and Instrur

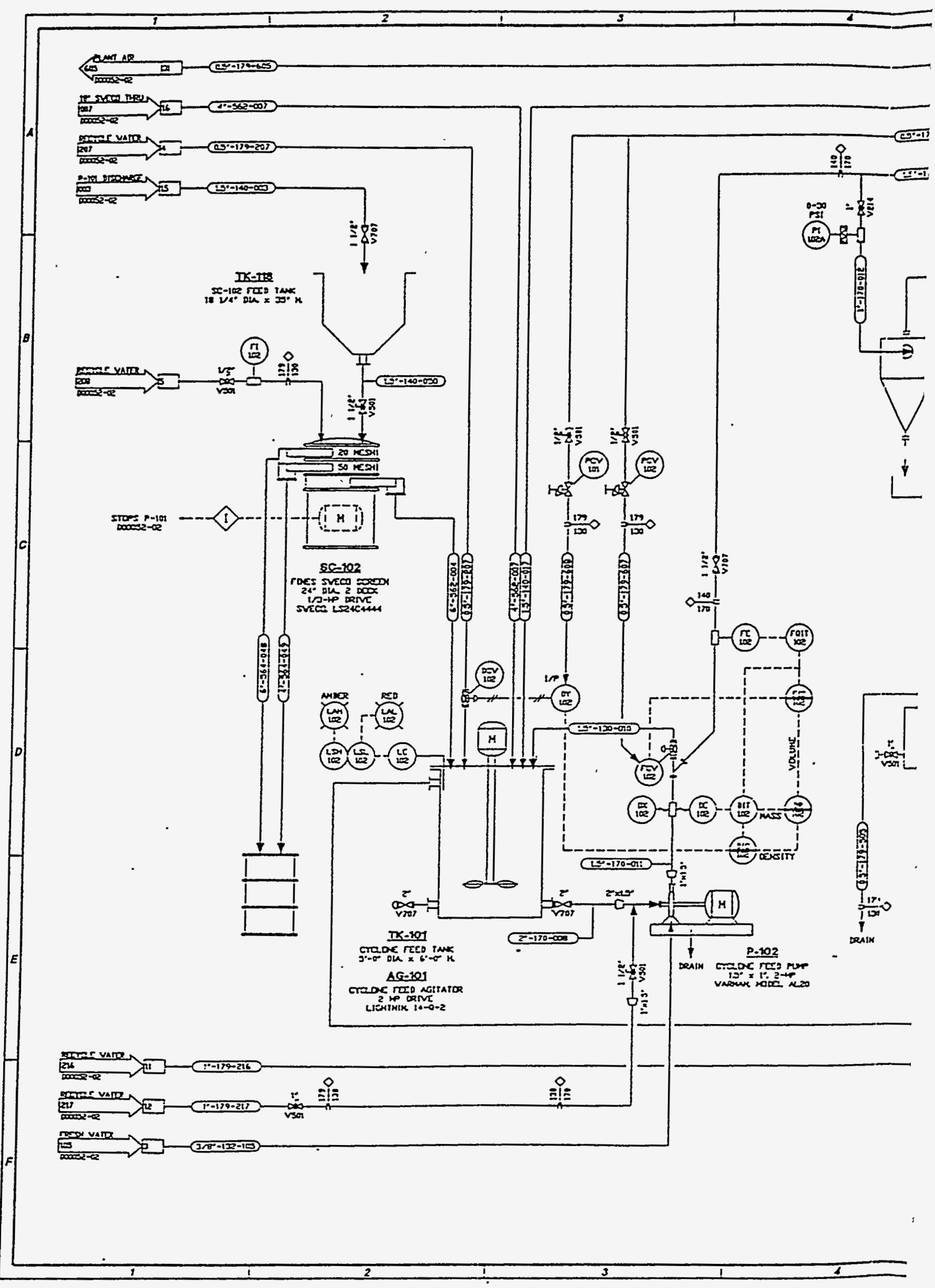



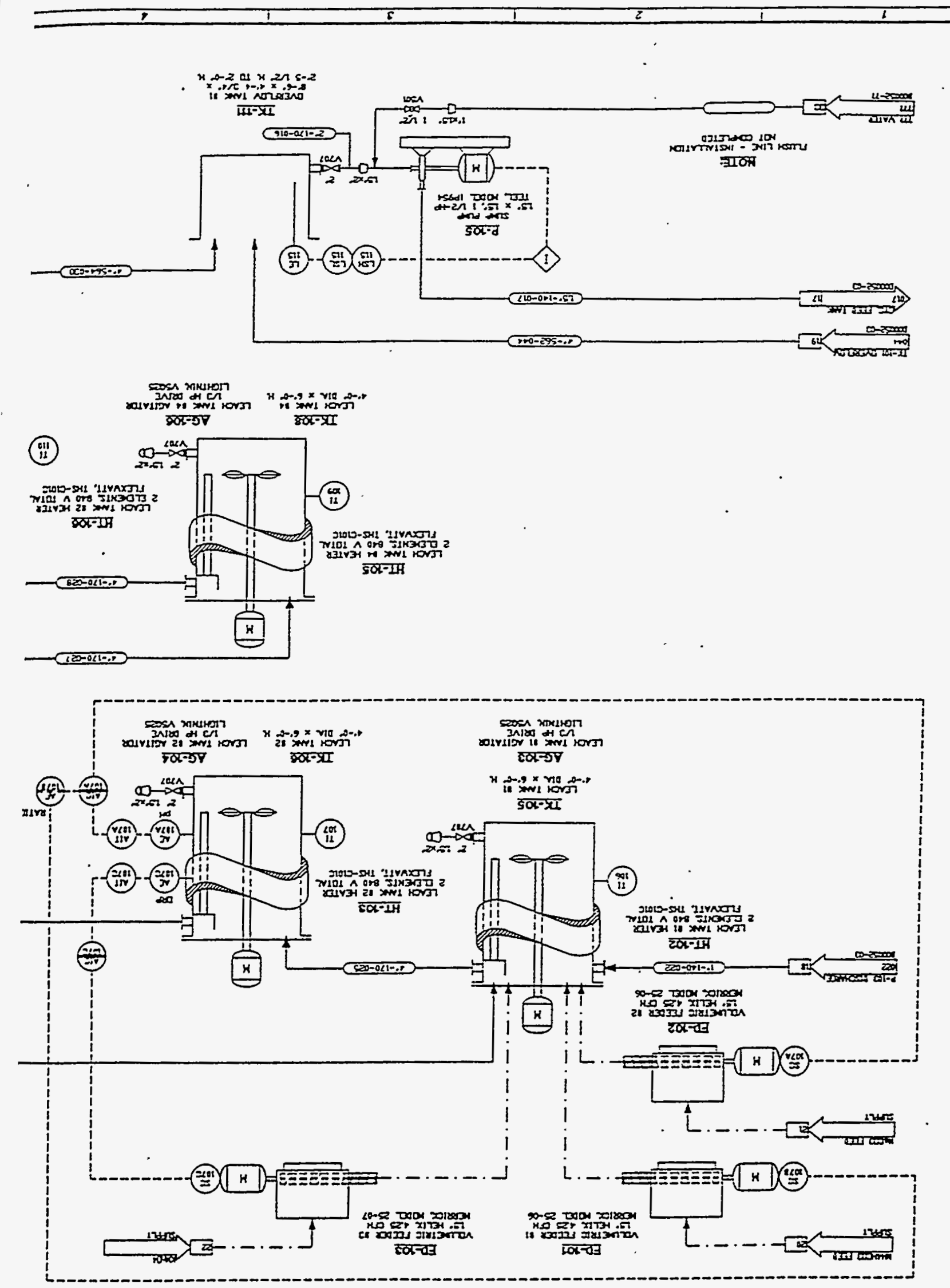

\section{Iəundłsu| pue 6u!d!d}




\section{Ientation, Diagram 4 of 4}

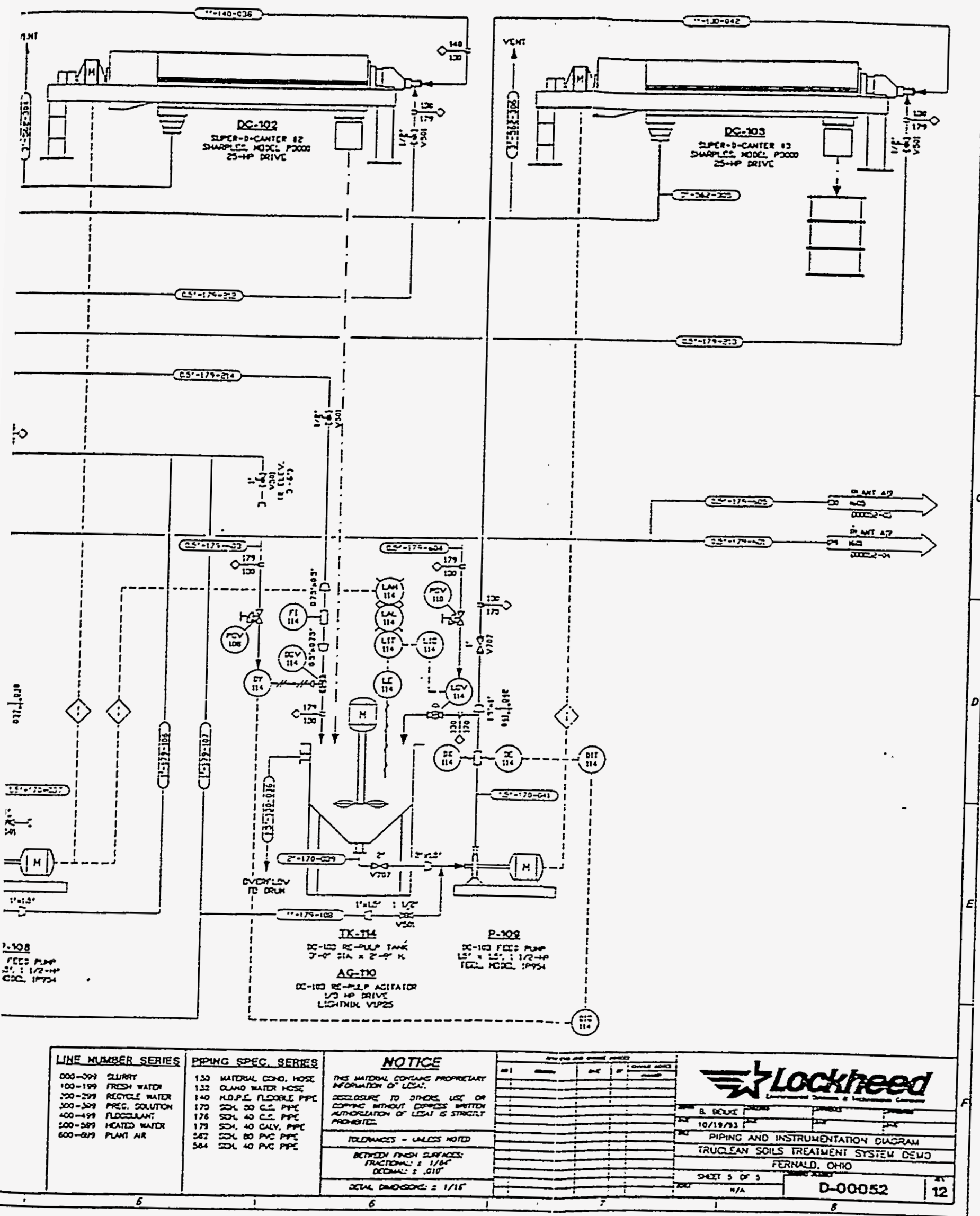




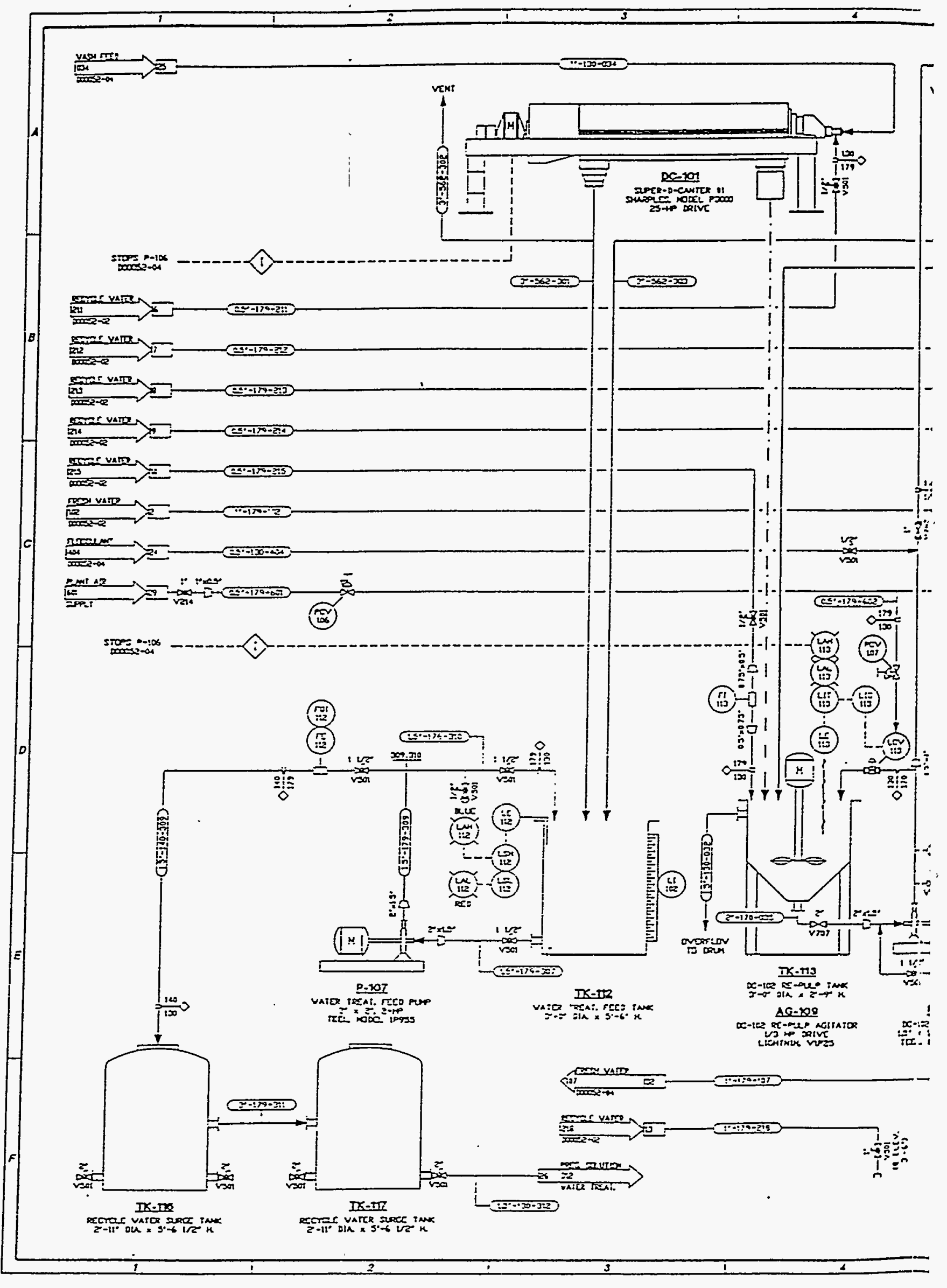


APPENDIX B.

CONVERSION FACTOR BETWEEN ACTIVITY AND CONCENTRATION FOR FERNALD CONTAMINATION SOIL 
For Fernald soils the technology screening level of $35 \mathrm{pCi} / \mathrm{g}$ is equivalent to a uranium level of $52 \mathrm{mg} / \mathrm{kg}$ of soil or $52 \mathrm{ppm}$ of soil. It is based on the distribution of uranium isotopes of naturally occurring uranium (U-234, 0.0055 percent; U-235, 0.72 percent; and U-238, 99.27 percent). Table B.1 lists the specific activities and their contribution to the total activity.

Table B.1. Specific Activities and Their Contribution to Total Radioactivity

\begin{tabular}{|c|c|c|c|}
\hline Wisotope & $\begin{array}{c}\text { MIass Distribution, } \\
\text { Percent }\end{array}$ & $\begin{array}{c}\text { Specifie Activity } \\
\text { e PCifg } \\
\end{array}$ & $\begin{array}{l}\text { Contributionito } \\
\text { Activitys p Cilg }\end{array}$ \\
\hline U-234 & 0.0055 & $6.13 \times 10^{9}$ & $3.37 \times 10^{5}$ \\
\hline U-235 & 0.72 & $2.14 \times 10^{6}$ & $0.15 \times 10^{5}$ \\
\hline U-238 & 99.27 & $3.3 \times 10^{5}$ & $3.28 \times 10^{5}$ \\
\hline Total & & & $6.8 \times 10^{5}$ \\
\hline
\end{tabular}

Therefore, $1 \mathrm{ppm}$ of natural uranium $=\underline{1 \mathrm{~g} \text { of natural uranium }}$

$10^{6} \mathrm{~g}$ of contaminated soils

$$
\begin{aligned}
= & \frac{6.8 \times 10^{5} \mathrm{pCi}}{10^{6} \mathrm{~g} \text { of soils }} \\
= & 0.68 \mathrm{pCi} / \mathrm{g} \text { of soils, or equivalently, } \\
& 1 \mathrm{pCi} \mathrm{U/g} \text { of soils }=1.47 \mathrm{ppm} \mathrm{P}
\end{aligned}
$$

Hence, $35 \mathrm{pCi} / \mathrm{g}=(35)(1.47)=51.5 \mathrm{ppm} \mathrm{U}$ 
Distribution for ANL-95/46

Internal:

J. M. Andrew

J. K. Bates

D. J. Chaiko

J. C. Cunnane (50)

W. L. Ebert
G. Edgell

J. E. Harmon

J. J. Laidler

R. Martello

J. J. Mazer
A. D. Pflug
D. M. Strachan
D. J. Wronkiewicz
TIS Files

External:

DOE-OSTI (2)

ANL-E Library

ANL-W Library

Manager, Chicago Operations Office, DOE

R. C. Baker, DOE-CH

A. Bindokas, DOE-CH

J. C. Haugen, DOE-CH

S. L. Webster, DOE-CH

J. Allison, USDOE, Office of Waste Management, Germantown, MD

A. Alm, USDOE, Office of Environmental Management, Washington, DC

T. D. Anderson, USDOE, Office of Science and Technology, Germantown, MD

M. Arndt, Lockheed Environmental Systems \& Technology, Pocatello, ID (5)

D. H. Bandy, USDOE, Albuquerque Operations Office, Albuquerque, NM

M. J. Barainca, USDOE, Office of Science and Technology, Washington, DC

J. E. Baublitz, USDOE, Office of Environmental Restoration, Germantown, MD

J. Bauer, USDOE, Office of Environmental Management, Germantown, MD

R. C. Bedick, USDOE, Morgantown Energy Technology Center, Morgantown, WV

M. Berger, Los Alamos National Laboratory, Los Alamos, NM

N. J. Beskid, Naperville, IL

D. Biancosino, USDOE, Office of Science and Technology, Washington, DC

J. Bickel, USDOE, Albuquerque Operations Office, Albuquerque, NM

D. Bottrell, USDOE, Office of Science and Technology, Washington, DC

G. Boyd, USDOE, Office of Science and Technology, Germantown, MD

M. Carter, USDOE, Germantown, MD

K. A. Chacey, USDOE, Office of Environmental Management, Germantown, MD

P. Colombo, Brookhaven National Laboratories, Upton, NY

J. Corones, Ames Laboratory, Iowa State University, Ames, IA

S. P. Cowan, USDOE, Office of Waste Management, Germantown, MD

J. J. Fiore, USDOE, Office of Environmental Management, Germantown, MD

C. W. Frank, USDOE, Office of Science and Technology, Washington, DC

W. Greenman, GTS/Duratek Corporation, Columbia, MD

J. Hall, USDOE, Nevada Field Office, Las Vegas, NV

L. H. Harmon, USDOE, Office of Environmental Management, Germantown, MD 
E. L. Helminski, Weapons Complex Monitor, Washington, DC

R. D. Hill, U.S. Environmental Protection Agency, Cincinnati, $\mathrm{OH}$

W. Holman, USDOE, San Francisco Operations Office, Oakland, CA

J. Hyde, USDOE, Office of Science and Technology, Washington, DC

S. James, U.S. Environmental Protection Agency, Cincinnati, OH

E. Koglin, U.S. Environmental Protection Agency, Las Vegas, NV

J. M. Lankford, USDOE, Office of Science and Technology, Germantown, MD

J. C. Lehr, USDOE, Office of Environmental Restoration, Germantown, MD

R. G. Lightner, USDOE, Office of Environmental Management, Germantown, MD

P. Lurk, USDOE, Office of Science and Technology, Washington, DC

A. P. Malinauskas, Oak Ridge National Laboratory, Oak Ridge, TN

S. A. Mann, USDOE, Office of Environmental Restoration, Germantown, MD

C. P. McGinnis, Oak Ridge National Laboratory, Oak Ridge, TN

J. Moore, USDOE, Oak Ridge Operations Office, Oak Ridge, TN

K. Morehouse, U.S. Environmental Protection Agency, Washington, DC

J. Paladino, USDOE, Office of Science and Technology, Germantown, MD

G. S. Patton, USDOE, Office of Science and Technology, Washington, DC

I. L. Pegg, GTS Duratek, Columbia, MD

M. Peterson, Pacific Northwest National Laboratory, Richland, WA

J. Poppiti, USDOE, Office of Science and Technology, Washington, DC

R. E. Prince, Duratek Corporation, Columbia, MD

P. A. Saxman, USDOE, Albuquerque Operations Office, Albuquerque, NM

J. Simpson, USDOE, Office of Science and Technology, Washington, DC

C. Sink, USDOE, Office of Science and Technology, Washington, DC

S. C. Slate, Pacific Northwest National Laboratory, Richland, WA

R. Snipes, Hazardous Waste Remedial Actions Program, Oak Ridge, TN

J. L. Steele, Westinghouse Savannah River Company, Aiken, SC

S. L. Stein, Battelle Seattle Research Center, Seattle, WA

L. H. Taylor, USDOE, Office of Environmental Restoration, Germantown, MD

J. A. Turi, USDOE, Office of Environmental Management, Germantown, MD

J. W. Wagoner, USDOE, Office of Environmental Restoration, Germantown, MD

J. Walker, USDOE, Office of Science and Technology, Washington, DC

R. D. Warner, USDOE, Fernald Field Office, Cincinnati, OH (4)

P. Wichlacz, EG\&G Idaho, Inc., Idaho Falls, ID

W. Wisenbaker, USDOE, Office of Environmental Management, Germantown, MD

J. L. Yow, Livermore, CA 


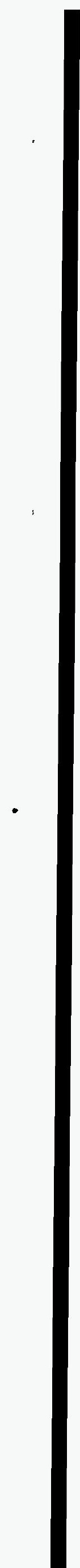

